\title{
ANARQUISTAS Y SINDICALISTAS EN LA PROVINCIA DE ALICANTE (1874-1917)
}

FRANCISCO MORENO SAEZ

\section{LA REPRESION DEL MOVIMIENTO INTERNACIONALISTA $D E A L C O Y$}

Tras los sucesos ocurridos en Alcoy en 1873, popularmente conocidos con el nombre de «el petrolio» - y que han sido estudiados por diversos autores ' - se desató, en el marco político propiciado por el golpe de Estado de enero de 1874 y en los primeros años de la Restauración, una fuerte represión sobre la clase obrera que sumió en la clandestinidad a los sectores organizados en la Asociación Internacional de Trabajadores. Lógicamente, y dadas las repercusiones que había tenido el movimiento internacionalista de Alcoy, esa represión se agudizó allí y a lo largo de 1874 y 1875 aparecen, en la prensa de Alcoy y en la de Alicante, frecuentes noticias sobre la detención, a veces «en despoblado», de hombres y mujeres calificados de "cabecillas de la Internacional» y considerados «instigadores» y «agitadores» en los sucesos que le costaron la vida a Agustín Albors ${ }^{2}$. La labor represiva fue llevada a término por el subgobernador de Alcoy, nombrado al efecto, y por el comandante militar de la plaza, en un ambiente de verdadero terror, llegándose incluso a realizar un «auto de fe» con algunas proclamas de

1 Desde el estudio clásico de FEDERICO ENGELS, Los bakuninistas en acción. Informe sobre la sublevación española del verano de 1873 (en MARX-ENGELS, Revolución en España. Ariel. Barcelona. 1970) hasta el panfleto de RAFAEL COLOMA, La Revolución Intenacionalista alcoyana de 1873. Instituto de Estudios Alicantinos. Alicante. 1951, pasando por estudios parciales en las obras de JOSEP TERMES, Anarquismo y sindicalismo en España. La Primera Internacional. 1864-1881. Ariel. Barcelona. 1972, CLARA E. LIDA, Anarquismo y revolución en la España del siglo XIX, Siglo XXI. Madrid. 1972, o C.A.N. HENNESSY, La República Federal en España, Aguilar. Madrid. 1966. Y sobre todo, RAFAEL ARACIL - M. GARCIA BONAFE, Classe obrera i cantonalisme a Alcoi (1873), en "L'Avenç», n. 13, febrero de 1979, o MANUEL CERDA, Els moviments socials del País Valencià, Institució Alfons el Magnánim. Valencia. 1981.

${ }^{2}$ «Ha sido capturada en Alcoy Concepción Torregrosa Colau, complicada en los sucesos de aquella ciudad, y sobre la que pesan vehementes sospechas de haber sido una de los más furibundos instigadores que condujeron a las turbas a cometer todo género de excesos» en "El Constitucional». (Alicante), 20-V-1874 / «Por fuerzas de la Guardia Civil de la línea de Jijona... fueron capturados anteanoche y en despoblado, Bautista Reig Moltó y Francisco de Paula Sánchez, internacionalistas y otros de los que tomaron parte en los sangrientos acontecimientos de Alcoy en los días 10 y 11 de julio de 1873» en «El Constitucional», 20-V-1875. 
la A.I.T. en abril de $1874^{3}$. En consecuencia, fueron encausados gran número de obreros, aunque algunos destacados dirigentes de la A.I.T., tales como Severino Albarracín, Francisco Tomás, Vicente Fombuena y Vicente Santonja, lograron escapar. Durante tres años, la Justicia se dedicó a interrogar a testigos y reos, que ascendieron a más de setecientos, algunos acusados en rebeldía. Poco a poco, sin embargo, los presos fueron abandonando la cárcel y en 1876 quedaban encarcelados en la ciudad ciento cuarenta y dos obreros, que se redujeron a dieciseis en 1881, tras un sobreseimiento, y a seis únicamente a partir de 1883.

La causa llenó treinta mil hojas, se sucedieron los jueces especiales y, a partir de 1876, hubo en Alcoy un movimiento popular para tratar de resolver el problema, que afectaba a toda la ciudad: se buscó el concurso del conde de Bernar para gestionar la amnistía ${ }^{4}$ y la prensa local trataba periódicamente el tema, perdido en los meandros de la burocracia judicial, al tiempo que advertía que la cuestión «mientras dure, será un mal fermento para Alcoy $)^{5}$. En diciembre de 1887, el Juzgado alcoyano dictó sentencia absolutoria, por falta de pruebas, para todos los acusados, sentencia que fue acogida con alegría en la ciudad, llegando incluso el Ayuntamiento a asistir en pleno a un «Te Deum» en acción de gracias ${ }^{6}$. La sentencia fue confirmada en octubre de 1888 por la Audiencia de Valencia, aunque por distintos motivos: de los reos, "gran parte de ellos fueron comprendidos en un indulto, otros se incluyeron en el sobreseimiento que se dictó, algunos han fallecido, bastantes son de ignorado paradero y contra los restantes no han resultado cargos concretos». Según los cálculos efectuados a partir de la documentación de la causa judicial por Aracil y García Bonafé7, la mayoría de los procesados eran hombres de edades comprendidas entre los 23 y los 48 años, casados, habitantes de la comarca de l'Alcoiá-Comtat y pertenecientes, sobre todo, a los sectores papelero y textil de la industria alcoyana. Había entre ellos un gran porcentaje de analfabetos que, sin embargo, era inferior al existente entre la población en general.

Además de esta represión "selectiva» se ejerció otra, más difusa, sobre toda la clase obrera alcoyana - paradigma, para la prensa oficial

${ }^{3}$ «El Constitucional», 30-IV-1874.

${ }^{4}$ JULIO BERENGUER BARCELO, Historia de Alcoy, 3 vols. Alcoy. 1977.

5 «El Serpis» (Alcoy) 11-V-1878.

${ }^{6}$ "Revista de Alcoy», 7-I-1888.

${ }^{7}$ R. ARACIL - M.G. BONAFE, Clase obrera y revuelta social: la identidad del cantonalismo alcoyano de 1873, en «Estudios de Historia social» n. 7. Madrid. 1978. 
y la sociedad bienpensante, de masa revoltosa-. En el informe que se evacua en Alcoy con ocasión de la constitución de la Comisión de Reformas Sociales, en 1884, se denunciaba el hecho de que los obreros que protestaban de las condiciones de trabajo se veían obligados a emigrar porque «su nombre circula entre los fabricantes», que les negaban el trabajo, así como a todo obrero asociado. Entre los obreros que intervienen en la información oral predomina, claramente, el escepticismo ante la viabilidad de medidas reformistas: es más, se llega a decir que las escasas intervenciones que se producen de obreros se deben "a la falta de fé en el resultado de la información». Como hiciera Jaime Vera en el informe presentado en Madrid, los obreros alcoyanos con mayor conciencia de clase - por ejemplo, José Seguí, que había sido procesado por los sucesos de 1873 -manifestaban su personal convencimiento de que entre capital y trabajo «la armonía no puede existir por entero». Pese a la represión, seguía predominando en el proletariado alcoyano la tendencia apolítica de la antigua A.I.T., que se ponía de relieve en las palabras de otro obrero que aseguraba que capital y trabajo eran enemigos por naturaleza y que los gobiernos sólo podian dictar leyes favorables al primero, por lo que «la política es desventajosa para el obrero" ${ }^{8}$.

Así las cosas, resulta lógico que el movimiento de inspiración anarquista tardase en reconstruirse, a pesar de las medidas liberalizadoras de Sagasta en 1881, que habían permitido la creación de la Federación de Trabajadores de la Región Española, a la que, según Max Netlau, pertenecían en la década de los ochenta cinco sociedades obreras de Alcoy, una de Concentaina, otra de Alicante y otra de Elche ${ }^{9}$. Algunas fuentes hablan de la celebración de un Congreso comarcal de la Federación de Trabajadores de la Región Española que se habría efectuado en Alcoy en el verano de 1885, pero del cual no informa la prensa del momento. En 1889 - cuando ya se habia disuelto, tras los sucesos de "La Mano Negra», la Federación de Trabajadores de la Región Española, a la que sustituiría la Organización Anarquista de la Región Española - se celebró un mítin anarquista en la plaza de toros de Alcoy ${ }^{10}$. Lo que podemos asegurar, sin embargo, es que en esas fechas el movimiento obrero alcoyano, el único que había alcanzado un cierto

${ }^{8}$ COMISON DE REFORMAS SOCIALES, Información oral y escrita en virtud de la Real Orden de 5 de Diciembre de 1883. Madrid. 1889-1892.

${ }^{9}$ A la luz de nuestros datos, creemos que no es cierta la existencia de ninguna sociedad obrera afiliada a la Federación de Trabajadores de la Región Española en Elche, donde en los años ochenta únicamente existía el Círculo Obrero Illicitano, entidad interclasista e influída, en todo caso, por simpatizantes del PSOE.

${ }^{10}$ "Revista de Alcoy», 3-VIII-1889, según JULIO BERENGUER, o.c. 
grado de organización en toda la provincia, volvía a estar dirigido - por ejemplo, en algunas huelgas parciales en el textil, en mayo, julio y septiembre de 1889 - por los anarquistas, como se demostraría en 1890, con ocasión de la primera manifestación conmemorativa del Primero de Mayo.

\section{EL PRIMERO DE MAYO DE 1890}

Cuando se acercó esta fecha, en que el proletariado mundial había decidido exigir de los poderes públicos la jornada de ocho horas de trabajo, en recuerdo de los mártires de Chicago, la prensa reaccionaria se apresuró a recordar los sucesos de 1873 y aseguró que habían llegado a Alcoy «anarquistas de otras partes para soliviantar y mover los ánimos; se han repartido hojas clandestinas, de las cuales algunas han llegado a nuestra ciudad proclamando todos los horrores del más bárbaro socialismo" ". Algunas familias adineradas abandonaron la población y la clase obrera se mostraba dividida, pues algunos querían manifestarse el día 4 - de acuerdo con las consignas socialistas- y otros pretendian declarar la huelga general: "los fabricantes están inquietos, pues conocen el carácter violento de esta población obrera" "2. Al final $-y$ a diferencia de lo que ocurrió en otros lugares de la provincia, como Elche, Crevillente o Alicante, donde la celebración del Primero de Mayo se llevó a cabo de acuerdo con las directrices socialistas - se impusieron en Alcoy los dirigentes anarquistas y en la tarde del lunes 5 de mayo, tras una manifestación en demanda de la jornada de ocho horas en la que tomaron parte dos mil obreros, se proclamó la huelga general 13. La población - para la que habían partido el día 27 de abril la mayoría de las fuerzas de la Guardia Civil existentes en Alicante - fue ocupada militarmente, interviniendo también las tropas del Regimiento de Vizcaya. Corría por la población la siguiente hoja, firmada por Antonio Miralles Casanova, que sería detenido en el curso de la huelga cuando ondeaba en "El Molinar» la bandera "de la sociedad de anarquistas»: «(Si volvemos al trabajo) seremos el desprecio de las demás localidades que hoy sostienen la lucha. $Y$ después la burguesía nos trataría como merecemos, que es como hombres cobardes y sin constancia, y la miseria más espantosa pesará sobre nosotros. ¿Qué se diria de los trabajadores de Alcoy, que una vez principiada la

" «El Alicantino», 29-IV-1890.

12 "El Alicantino», 23-IV-1890, que toma la información de "El Imparcial».

13 "Revista de Alcoy», 10-V-1890. 
lucha nos pusiéramos a trabajar sin haber conseguido nuestra demanda de ocho horas por jornada, y más pedida por todos los obreros del Universo? Antes de llegar a este paso, que se abra la tierra y perezcamos todos en sus ruinas, y de esta manera salvaguardaremos nuestra dignidad de hombres y de trabajadores" ${ }^{14}$.

Tras algunas gestiones del Gobernador Civil - que se reunió con los presidentes de las Sociedades Obreras y les hizo diversas promesas ${ }^{15}-$ los trabajadores alcoyanos se mantuvieron firmes, pues apenas cuatrocientos de los miles de huelguistas se mostraron dispuestos a volver a las fábricas, a pesar del aumento de la miseria y de los empeños, más de doscientos diarios, en el Monte de Piedad. Al cabo de una semana de huelga, y al conocer el fracaso de la jornada en el resto de España y del mundo, los obreros alcoyanos regresaron al trabajo, sin lograr la jornada de ocho horas, pero habiendo demostrado su combatividad.

Ante el Primero de Mayo de 1891, «El Liberal» de Madrid publicaba una serie de artículos sobre la cuestión social y sobre las perspectivas que presentaba la fecha en las poblaciones industrializadas españolas. El corresponsal enviado a Alcoy describía las distintas tendencias existentes entre los obreros alcoyanos y, en relación a los anarquistas, decía:

«La Federación Alcoyana es el título que lleva la agrupación anarquista, que tiene un centro donde se congregan, divididos en agrupaciones, más de 400 colegas.

Es alma de esa agrupación José Seguí, hombre de cincuenta y cuatro años, de oficio tejedor, de poca instrucción, pero de una astucia finísima.

Seguí es muy conocido desde los sucesos ocurridos en esta población en 1873, a consecuencia de los cuales estuvo preso bastante tiempo en Alicante.

La Federación Alcoyana es partidaria de la huelga hasta conseguir la jornada de ocho horas, y su influencia la lleva a los trabajadores del ferrocarril de Gandía a Alcoy... el número de trabajadores se acerca a $2.000{ }^{16}$.

En 1893 se produjeron ciertos hechos relacionados con los anarquistas alcoyanos que demuestran el temor, infundado, que las organizaciones anarquistas provocaban en las autoridades: una noche del mes

14 «El Alicantino», 10-V-1890.

${ }^{15}$ «1/ Todos los patronos admitirán a los mismos obreros, con igual jornal y jornada que antes. $2 /$ Cuando en otras naciones se acepten las ocho horas, aquí también. 3/ Ningún patrono podrá despedir a nadie por represalias».

${ }^{16}$ «El Liberal» (Madrid), 20-IV-1891. 
de febrero la ciudad fue ocupada por tropas de Infantería y de la Guardia Civil, al conocer por confidentes las autoridades que los anarquistas de Alcoy y Cocentaina tenían el proyecto de alzarse en armas y promover un motín en el que incendiarían las notarías, los archivos y las Casas Consistoriales y volarían con dinamita edificios públicos y privados. La Guardia Civil registró las casas de «los más furibundos anarquistas" ${ }^{17}$. Al día siguiente, regresaron a sus lugares de procedencia las fuerzas de la Guardia Civil que habían llegado a Alcoy. Según la prensa adicta al régimen, el complot era auténtico y fue impedido por las acertadas medidas de las autoridades; según otros periódicos, no se trató más que ridículas habladurías ${ }^{18}$. De todos modos, se ejercía así una constante y eficaz presión sobre la organización obrera anarquista alcoyana, secundando con hechos la campaña de prensa con ocasión de los atentados terroristas efectuados, casi siempre a título individual, por determinados ácratas.

En el resto de la provincia, no parece que tuviesen mucha implantación los anarquistas entre 1890 y 1895 . La clase obrera de la capital alicantina estaba más bien influída por republicanos y socialistas. En 1892, ante los hechos de Jerez, el periódico católico «El Alicantino» se complacía en considerarlos consecuencias del liberalismo y las leyes desamortizadoras ${ }^{19}$, pero admitía que en Alicante no se habían producido las reacciones que en otros lugares: «entre los obreros alicantinos dominan temperamentos de prudencia y cordura que les honra y enalte(ce $\gg{ }^{20}$. Pero las autoridades vigilaban y ante la bomba del Liceo barcelonés - en la que aparece implicado el alcoyano Bautista Cervera - recoge "La Monarquía» el rumor de que el Gobierno Civil iba a revisar los reglamentos de las Sociedades Obreras existentes en la provincia "para ver si en algunas hay tendencias al anarquismo»"

En 1894, ante el auge del anarquismo andaluz, «El Alicantino» - que

17 "La Alianza Obrera» (Alcoy), 24-II-1893 / «El Serpis», 23-II-1893.

18 Para el alicantino "La Tarde», se trataba de un problema interno que había excitado a los anarquistas, que venían preparando un golpe de mano contra la burguesía. / Para "La Unión Republicana» (Alicante), 4-IV-1893, todo eran ridículas habladurías.

${ }^{19}$ "El Alicantino», 7-II-1892 / También, Socialismo y anarquismo, en «El Alicantino", 26-IV-1890: todo se vuelve contra los desamortizadores: "¿Qué diferencia hay entre los anarquistas y los demás liberales doctrinarios y oportunistas, sino un simple accidente de grado?».

${ }^{20}$ «EI Alicantino», 7-II-1892 / «El espíritu que anima a los obreros de esta población es hostil a las ideas anarquistas, y reprueban unánimemente los recientes sucesos de Jerez. («El Alicantino», 14-I-1892).

${ }^{21}$ "La Monarquía» (Alicante), 26-IX-1893 / Véase también Los sucesos de Barcelona o la libertad de la fiera, en "La Monarquía», 11-XI-1893. 
dedicó numerosos artículos al tema ${ }^{22}$ - tranquilizaba a sus lectores: «En Alicante debemos decir que los anarquistas, en el propio sentido de la palabra, no existen, pues no deben contarse como tales una docena de ilusos descreídos, que bien por la solapada propaganda del masonismo, bien por la mala educación que han recibido, se proclaman ateos y sueñan en reformar la sociedad. En Alicante no existiria esa docena de descontentos si volviese la prosperidad de otros días» ${ }^{23}$.

\section{LOS ANARQUISTAS EN EL TRANSITO DEL XIX AL XX}

Entre 1895 y 1906, y contrariamente a lo que han sostenido algunos autores ${ }^{24}$, el anarquismo no experimentó demasiados progresos ni en el campo, donde predominaba el catolicismo social, ni en las ciudades que contaban ya con algunos talleres, con la salvedad de Alcoy, donde los anarquistas tuvieron un importante papel en las huelgas textiles habidas en los últimos años del siglo XIX, especialmente en la del verano de 1895, en la que hubo enfrentamientos físicos con los esquiroles y numerosos detenidos. Al margen de esa organización alcoyana - que tampoco estaba tan definida como años atrás en un sentido anarquista - , creemos que apenas habría una docena de simpatizantes de las ideas libertarias en la capital de la provincia y algún pequeño grupo en Elda, y tal vez en Elche, pero sin la menor influencia sobre el conjunto de los trabajadores.

En el último lustro del siglo XIX, la persecución gubernamental contra el anarquismo - proyecto de Ley de represión del anarquismo y creación de la policía especial, torturas contra los presos anarquistas en Mont-

22 En «El Alicantino» pueden leerse varios artículos de este estilo: Los peligros anarquistas (16-II-1892), Los mandamientos del anarquismo (8-IV-1892), El proceso de los anarquistas (17-11-1894), Otra vez los anarquistas (18-11-1894), Los anarquistas (24-1I-1894), Misterio anarquista (13-III-1894), El anarquismo. Estudio sobre la cuestión social (15-I-1895): este último es una recensión de la obra del portugés Serga y Pimentel, que traduce Alvarez Sereix.

${ }_{23}$ "El Alicantino», 11-VII-1894 / El 8-VIII-1894 comenta los rumores - que juzga infundados - de la llegada a Alicante de ocho anarquistas «llevando siniestros propósitos».

24 JUAN ROMERO GONZALEZ, Orígenes del movimiento obrero valenciano en el tránsito del siglo XIX al XX. Del Cénia al Segura. Valencia. 1979. Pg. 263. Habla de incuestionables progresos del anarquismo en el campo, pero nos tememos que funciona aqui la frecuente extensión a todo el País Valenciano de lo que ocurría en Valencia y la comarca de l'Horta: no existe tal presencia anarquista en el campo alicantino. 
juich, etc. - provocó la solidaridad entre socialistas y republicanos alicantinos, que organizaron mítines de protesta en 1896 y $1897^{25}$.

A primeros de siglo, en 1902, los anarquistas habian lanzado, desde las páginas de "La huelga general» y "Tierra y Libertad», la idea de que la huelga general era, por así decirlo, la panacea universal para resolver de una vez por todas la injusta situación de la clase obrera. Cuando esta propuesta fue llevada a la práctica en Barcelona, las autoridades alicantinas volvieron a tomar precauciones y concentraron en Alcoy tropas del Regimiento de la Princesa, de Alicante, que se unieron a las alli estacionadas del Regimiento de Vizcaya: según la prensa, temían que el proletariado alcoyano, "tan sensible a las tácticas anarquistas», se uniese al paro general, cosa que no sucedió ${ }^{26}$.

Como es sabido, la huelga general provocó duros enfrentamientos entre el movimiento obrero anarquista y el socialista, pues ni la UGT ni el PSOE apoyaron el paro general. De ahí que uno de los ejes fundamentales de la propaganda socialista en esos años sea el intento de marcar diferencias con los ácratas, criticando determinadas actuaciones y propuestas ideológicas. En el semanario socialista alicantino «El Mundo Obrero" se encuentran numerosos ejemplos de esta polémica que, sin embargo, creemos era debida más bien al espíritu disciplinado de los dirigentes socialistas de la época que a una auténtica presencia anarquista entre el proletariado alicantino, de nuevo con la excepción de Alcoy. Se contraponían los atentados terroristas, la falta de cultura y la descabellada huelga general de los anarquistas a la prudencia y al carácter "científico» de la teoría socialista ${ }^{27}$.

${ }_{25}$ Mitin que organizan los socialistas en junio de 1896 contra el proyecto de ley contra el anarquismo («El Nuevo Alicantino», 28-VI-1896) / Artículos que sabemos publicaba el semanario socialista «El grito del pueblo», por alusiones en «El Nuevo Alicantino" / "La Federación» (Alicante), 16-V-1897: alusión a los tormentos de Montjuich / Incluso el moderado "El Graduador» (Alicante), 12-IX-1897, reconoce: «en un pais donde la justicia anda escasa y la moralidad no se conoce, tiene abono para que los anarquistas se multipliquen».

${ }^{26}$ "La Vanguardia» (Alicante), 4-III-1902.

${ }^{27}$ Frente a la Huelga general, que destroza a las sociedades de resistencia, que es fruto de la «ilusión, ignorancia, fanatismo», había que oponer la huelga por sectores, apoyada por otros compañeros que trabajasen: "El Mundo Obrero» (Alicante), 15-IX-1901. 9-II y 27-VII-1902. Había que propiciar la cultura de los obreros, pues las teorías anarquistas sólo hallarán «eco su estupidez en el corazón de alguna parte de los trabajadores mientras subsista la crasa ignorancia que predomina en el pueblo») (EI último fracaso, en «El Mundo Obrero», 2-VIII-1903). Se repudiaban, asimismo, los atentados personales, como algo inhumano y estéril: "Querer combatir el régimen social burgués o las instituciones que lo defienden llevando a cabo actos criminales contra las personas que los representan es tan torpe como estériles y contraproducentes son 
Incluso, en esos primeros años del siglo $X X$, los socialistas llegaron a disputar a los anarquistas su feudo alcoyano, donde lograron cierta implantación - si bien entre los obreros de sectores de la producción de menor importancia, pues en el textil parece que fue incontestable el predominio anarquista - : en «El Mundo Obrero» hay referencias al intento ácrata de hacer ingresar a las sociedades obreras alcoyanas en «la tan cacareada Federación Regional»" ${ }^{28}$, a la división existente en la clase obrera alcoyana - «hállanse hoy separadas en dos locales las cuatro únicas sociedades que existen ${ }^{29}-$, etc. Los socialistas predominaban en el Centro Obrero Instructivo y los anarquistas alcoyanos trataban de plantear en repetidas ocasiones controversias con los socialistas en torno a la huelga general y a los artículos que publicaban «El Mundo Obrero» y «El Corsario» ${ }^{30}$.

En el resto de la provincia, el movimiento obrero organizado que existía en los primeros años del XX estaba influído por los socialistas, especialmente el sector de la alpargata de Elche, donde se produjo en 1903 una huelga que iba a servir a los dirigentes de la UGT y del PSOE como ejemplo de las ventajas de las huelgas localizadas sobre la huelga general ${ }^{31}$. Los escasos núcleos anarquistas que existían en Elche, Alicante o Elda trataban de suscitar mitines de controversia con los socialistas ${ }^{32}$ y recibian algún apoyo de la prensa republicana $y$, especialmente, de "La Federación», órgano de los republicanos federales ${ }^{3}$.

sus resultados» (El último atentado, en «El Mundo Obrero», 24-IV-1904). En suma, para los socialistas alicantinos, los anarquistas tenían como único objetivo el dividir a la clase trabajadora y se llega a decir que «el anarquismo es el arma de que se aprovecha el jesuitismo ( $\mathrm{sic}$ ), para destruir el grandioso movimiento de concentración del proletariado consciente del Universo» (LEGNA, ¿Quiénes son y qué se proponen los anarquistas?, en «El Mundo Obrero», 28-VII-1901).

28 «El Mundo Obrero», 8-IX-1901.

${ }^{29}$ «El Mundo Obrero», 9-III-1902.

${ }^{30}$ "El Mundo Obrero", 3-VIII y 14-IX-1902 y 30-VIII-1903.

${ }^{31}$ Torpezas ácratas, en «El Mundo Obrero», 28-VI-1903.

${ }^{32}$ Así, en Elche, Fidel González retó a Verdes Montenegro, Pablo Iglesias y al dirigente socialista local Vives «para discutir lo funesta que es la politica para la clase trabajadora» («EI Mundo Obrero», 1-VI-1902) / En ese mismo mes, se pidió permiso para un mitin de Constancio Romeo, en la plaza de toros de Elche, sobre «Influencia perjudicial del PSOE en la clase trabajadora». (Folleto en el Archivo Municipal de EIche) / También polemizaron los ácratas con los republicanos («El Mundo Obrero», 14-VII-1901, alude a una polémica entre Tárrida del Mármol y los republicanos alicantinos Berenguer, Cabot y Sevilal.

33 "La Federación» ataca a los socialistas - que también trataban de desmarcarse de los republicanos - en defensa de Constancio Romeo y otros librepensadores cercanos al anarquismo, ataque que se agudizó al socaire del problema del anticlericalismo de esos años. 
En 1906 y a consecuencia del atentado de Mateo Morral contra el rey el 31 de mayo, se reprodujeron los ataques al anarquismo desde la prensa burguesa ${ }^{34}$ y fueron detenidos Nakens y Ferrer Guardia. En febrero de 1907 hubo una reunión en Alcoy - donde nuevas generaciones anarquistas, cercanas a las posiciones de Teresa Claramunt y Leopoldo. Bonafulla, iban sustituyendo a los antiguos militantes de los sucesos de 1873-, entre las sociedades obreras y las entidades políticas de izquierda, para organizar la campaña de protesta contra el proceso que iba a celebrarse contra Nakens y Ferrer. En esta campaña tuvo una intervención muy destacada el republicano radical Botella Asensi, que sería procesado por unos artículos en contra de Maura publicados en "Fraternidad», en los cuales se invitaba a los liberales a asistir al mitin que se llevó a cabo el día 7 de abril «para pedir no que se absuelva a los culpables, sino que no se condene a inocentes». En este mitin se pidió al Gobierno que «en el proceso incoado con motivo del crimen de la calle Mayor no se condene sin poseer pruebas materiales de la culpabilidad de los procesados» ${ }^{35}$. En esos momentos - sin duda, debido en parte a la campaña en favor de Nakens y Ferrer ${ }^{36}$ - se produjo en Alcoy un gran acercamiento entre anarquistas y republicanos; la iniciativa de los correligionarios de Botella Asensi de crear una Casa del Pueblo - que controlará el partido radical, al amparo de la posición de Botella Asensi en el Ayuntamiento alcoyano - fue bien acogida en los medios obreros cercanos a los anarquistas y con reticencias entre los socialistas, que al final cederán en su oposición y se integrarán en la comisión que prepara la Casa del Pueblo ${ }^{37}$. El periódico alicantino "Diario de Alicante», que envió a unos redactores a Alcoy para informar a sus lectores sobre la huelga textil del verano de 1907, aseguraba que el proletariado de aquella ciudad estaba dividido en cuatro opciones ideológicas: la católica, la socialista, la republicana radical y la anarquista. Advertía también de la existencia de numerosos agitadores «encargados de manejar a la masa obrera a su antojo, llevándola por descarriados caminos, con el pretexto de hacer su felicidad ${ }^{38}{ }^{38}$. Precisa-

34 Por ejemplo, «Heraldo de Alcoy», 19-VI y 4-VIII-1906 (La represión del anarquismol.

${ }_{35}^{35}$ "Fraternidad» (Alcoy), 13-IV-1907.

${ }^{36}$ La campaña había comenzado con un mitin celebrado el 13 de enero ( Fraternidad", 17-I-1907), en el que se leyó una hoja de Federico Urales, titulada Por la Justicia y por España / Véase también «Fraternidad», 9-II y 30-III-1907.

${ }^{37}$ El hecho de que Nakens y Ferrer fuesen dos campeones del anticlericalismo y. de la educación laica explica también la gran acogida que su proceso tuvo en las filas anarquistas / Véase también «Fraternidad», 30-III, 13 y 27-IV, 25-V , 6, 13 y 20-VII-1907.

${ }^{38}$ "Diario de Alicante», 7-VIII-1907. 
mente en esa huelga textil se acordó, tras una intervención del anarquista Claramunt en un mítin al que asistieron unos dos mil obreros, plantear la huelga general ${ }^{39}$.

Hemos de advertir que, salvo en estas ocasiones excepcionales, apenas tenemos información sobre la actividad y el desarrollo del anarquismo en la provincia de Alicante en estos años, no sólo por la falta de acogida que ante ellos muestra la prensa burguesa, sino sobre todo por la falta de prensa anarquista y de datos procedentes de las propias filas libertarias. Las monografías que Manuel Buenacasa recoge en su obra sobre el movimiento obrero español, apenas ofrecen datos sobre la provincia de Alicante ${ }^{40}$. Según este dirigente sindicalista, «pasados, idos los tiempos internacionalistas, llenos de impetuosidad y doctrinarismo, el Levante productor había caído en un sopor, en una abulia poco menos que renunciadora y suicida».

A finales de 1907 comenzó la agitación entre la oposición ante los rumores de que se preparaba por el Gobierno de Maura una ley contra el terrorismo, al amparo de las bombas que ponía, en esas fechas, el confidente y agente de la policía Rull ${ }^{41}$. La política de Maura estaba claramente dirigida contra el movimiento obrero organizado, pues al mismo tiempo que se presentaba la citada Ley contra el Terrorismo se discutía en el Senado un proyecto de ley sobre la huelga. Ante esta ofensiva legislativa, las izquierdas españolas reaccionaron vigorosamente: en abril de 1908 se celebraron mítines en Alicante contra la Ley de huelgas y la política de Maura ${ }^{42}$ y en mayo dió comienzo una fuerte campaña para frenar el proyecto de ley contra el terrorismo: ya en marzo se había organizado en Alcoy un mitin en la Escuela de Párvulos contra el sopechoso terrorismo de Barcelona ${ }^{43}$. A finales de mayo se recogieron firmas en Alcoy y Alicante para enviar al Congreso de los Diputados el siguiente texto:

"Los infrascritos, vecinos de..., ruegan al Congreso de Diputados rechace el proyecto de ley reformando la de delitos cometidos.

39 «Diario de Alicante», 15, 16 y 17-VIII-1907 / «El Demócrata» (Alicante), 18-VIII-1907.

40 "Ni Alcoy, ni Cullera, ni el Grao, ni Sueca, ni Alicante, ni las sierras de Cartagena... aparecen a nuestra vista aquí): MANUEL BUENACASA, El movimiento obrero español. Historia y crítica (1886-1926). París. 1966.

${ }^{41}$ Sobre Rull puede verse GILLES LAPOUGE - JEAN BECARUD, Los anarquistas españoles. Anagrama. Barcelona. 1972. Pg. 65.

42. «El Graduador», 15-IV-1908 / Para este diario (13-V-1908) «el terrorismo, tenemos la íntima seguridad de que se combate con medidas de cultura, más que con medidas de represión».

${ }^{43}$ "Fraternidad», 4-IV-1908. 
por medio de explosivos, estimando que infringe los principios constitucionales» ${ }^{44}$.

$Y$ en las primeras semanas de junio de 1908 se organizaron numerosos mítines contra el proyecto de ley: en Elche, el anarquista José Galiano solicitó el permiso para el mitin, que se llevó a cabo el 6 de junio ${ }^{45}$; en Alcoy asistió una enorme concurrencia, más de cuatro mil personas ${ }^{46}$. En Alicante se celebraron tres mítines, organizados respectivamente por los anarquistas, los socialistas y los republicanos, aunque colaboraron también los liberales dinásticos. No cuajó la propuesta de «Diario de Alicante» de organizar un mitin conjunto ${ }^{47}$. El día 7 se celebró en el Teatro Circo un mitin «respondiendo al gesto de indignación que en España entera se promueve contra el monstruoso y absurdo proyecto de ley de represión del terrorismo», que organizaron los anarquistas. La concurrencia «no es muy numerosa» - lo que indicaría, frente a los otros mítines, que tuvieron mayor eco, la escasa implantación de los anarquistas en la ciudad de Alicante-. Carlos Botella dio lectura a varias adhesiones. Intervinieron Juan Gomis, Valverde - que «pide que se apruebe el proyecto famoso para conseguir que el obrero sea de una vez hombre y conquiste por la fuerza los derechos que hoy mendiga humildemente»-, Aguilar - redactor del periódico ácrata valenciano «Humanidad Nueva»-, Aguado - en nombre de los anarquistas de Elche-, el anarquista catalán Solá y el republicano doctor Rico. Los asistentes aprobaron por unanimidad las siguientes conclusiones:

«1. - Los defensores de la democracia española esperamos sea pronto ley la proyectada contra el terrorismo.

2. - Sabemos conculca la Constitución, pero estimamos que aprobada ardería España por los cuatro costados, acabando con todas las leyes de excepción que cual el actual proyecto aten-

${ }^{44}$ «Fraternidad» y "Diario de Alicante», 30-III-1908 / En Alicante se recogen firmas en el Centro de Sociedades Obreras, el Círculo Republicano, el Centro de Escritores y Artistas y «Diario de Alicante».

${ }^{45}$ Puede verse la instancia en el ARCHIVO MUNICIPAL DE ELCHE, Legajo 50 / "La Correspondencia de Alicante», 9-VI-1908: al mitin asisten unas 3.000 personas y el orador Solá asegura que las autoridades y la policía catalanas eran los autores de las acciones terroristas.

46 "Fraternidad", 6-VI-1908 / Preside el obrero Francisco Martínez y hablan Eduardo Marhuenda (colaborador de «Fraternidad»), los obreros César Ruíz y Ramón Esplugues, el periodista Gonzalo Barceló, el socialista Salvador Palacios, Ricardo Gil, que lo hace en valenciano, y el líder republicano Botella Asensi. Al final, se adhieren a las conclusiones del mitin celebrado en Madrid.

${ }^{47}$ «Diario de Alicante». 3 y 5-VI-1908 / Ello, pese a la adhesión a la idea de «La Unión Democrática», "El Demócrata», «El Graduador», el Centro de Sociedades Obreras, la Juventud Alicantina, politicos liberales, socialistas y republicanos, etc. 
tan a nuestras libertades individuales reconocidas constitucionalmente.

3. - Aceptamos para anular las leyes todas de excepción el concurso de todos los elementos sociales que combaten a toda clase de gobierno que represente al actual régimen ${ }^{48}$.

Poco después se celebró en el Centro de Sociedades Obreras el mitin que organizaban los socialistas ${ }^{49}$ y otro, en el Teatro Principal, que organizaron republicanos y liberales: hablaron en este último el director de "Diario de Alicante» Emilio Costa, los republicanos E. Irles, Rafael Sevila y Juan Botella Asensi ${ }^{50}$ y los liberales dinásticos Ortega y Gasset y Francos Rodríguez. Las conclusiones aprobadas fueron las siguientes:

«1. - Protestar del intento que significa el proyecto de ley llamado del terrorismo.

2. - Proclamar la necesidad de que la España liberal, fuerte al estar unida, destruya la obra de los que quieren obligarle a retrasar el curso de su historia.

3. - Adherirse a la campaña que en toda España se realiza contra los propósitos del Gobierno» ${ }^{51}$.

Como es sabido, esta campaña tuvo éxito y Maura retiró el proyecto de ley del Parlamento ${ }^{52}$.

\section{DE "SOLIDARIDAD OBRERA» A LA CONFEDERACION NACIONAL DE TRABAJADORES}

En general, en estos primeros años del siglo los grupos anarquistas no tenían mucha influencia entre la clase obrera: Alcoy era la excepción, aunque el predominio anarquista sobre la clase obrera alcoyana estaba en cuestión por la presencia socialista, el influjo de los republicanos de Botella Asensi y, sobre todo, por la represión de las autoridades: así, en marzo de 1909 fueron detenidos bajo la acusación de ser anarquistas Enrique Catalá, Salvador Palacios y Camilo Monllor - y

${ }^{48}$ «Diario de Alicante», 8-VI-1908 / «El Graduador», 9-VI-1908. Al parecer, Solá era redactor de «Tierra y Libertad». Según la prensa, el local, castigado por el sol, restó mucho público («El Demócrata» y «La Correspondecia de Alicante», 8-VI-1908 / «Heraldo de Alicante», 8-VI-1908).

${ }^{49}$ «Diario de Alicante», 15-VI-1908 / «La Federación», 17-VI-1908.

${ }^{50}$ Cuyo discurso recoge integro «Fraternidad», 20-VI-1908.

${ }^{51}$ "Diario de Alicante», 12-VI-1908 / Más información en el «Heraldo de Alicante» y «El Demócrata», 12-VI-1908, "Diario de Alicante» 15-VI-1908 y "La Federación», 17-VI-1908.

${ }^{52}$ El triunfo, editorial de «El Demócrata», 1-VI-1908, comentando la retirada por el gobierno de este proyecto de ley tachado por todos los demócratas de reaccionario. 
al día siguiente, cuando acudian a llevarles comida, también fueron detenidos José Gironés y Camilo Nieto - , pero los obreros obtuvieron del alcalde que gestionase su libertad ${ }^{53}$. Los anarquistas "puros», sin embago, rechazaron hasta 1907 la actuación sindicalista y vegetaban, escasos en número, sin auditorio ni influencia sobre las masas ${ }^{54}$. La situación comenzó a cambiar con la fundación de "Solidaridad Obrera» en agosto de 1907.

Aunque, como ha demostrado Xavier Cuadrat ${ }^{55}$, "Solidaridad Obrera» se fundó en 1904, fue en el verano de 1907 cuando se procedió a su reorganización y extensión. En esos primeros años del siglo $X X$ hubo una gran interacción entre el movimiento obrero catalán y el francés: en 1902 el socialista Millerand entró en el gobierno de Waldeck Rousseau y en 1905 los diferentes partidos socialistas se fusionaron en la SFIO, que dirigía Jean Jaurés. En 1906 se celebró por la C.G.T. el Congreso de Amiens, donde triunfó la postura que propugnaba la independencia del movimiento sindical de todo partido político (la llamada "Carta de Amiens»). Este "sindicalismo revolucionario» habría de tener gran influencia en el movimiento obrero catalán, ejerciendo también un claro influjo sobre la C.N.T.

«El carácter economicista y pragmatico del sindicalismo explica la colaboración de socialistas, republicanos, antiguos anarquistas y nuevos sindicalistas en el seno de "Solidaridad Obrera», afirma Cuadrat. En efecto, aunque los ácratas intervinieron activamente en la formación de "Solidaridad Obrera», esta organización no llegó a adoptar un programa abiertamente libertario por la presencia de destacados socialistas, como Antonio Badia, y sectores puramente sindicalistas. El apoyo de Ferrer se limitó a financiar en parte el local y el periódico de «Solidaridad Obrera». En septiembre de 1908 se celebró el Congreso Obrero de Cataluña, donde se constituyó la llamada "Confederación Regional de Sociedades de Resistencia Solidaridad Obrera», con una participación importante de los socialistas catalanes - en tanto que la UGT apenas contaba con 6 secciones en Barcelona y ninguna en el resto de Cataluña-. Al calor de este Congreso surgieron, probablemente impulsados por los ácratas, intentos de reorganización de los Sindicatos en varias localidades españolas, concretamente en Gijón, Jerez, Montilla y Alcoy. No parece cierto, como asegura Pestaña, que estas sociedades obreras pidieran el ingreso en "Solidaridad Obrera», porque esta era una organización regional, pero se las consideró adheridas.

53 «Fraternidad», 20-III-1909.

${ }^{54}$ CESAR M. LORENZO, Los anarquistas españoles y el poder.

${ }^{55}$ XAVIER CUADRAT, Notas sobre el movimiento obrero catalán: los socialistas y "Solidaridad Obrera» (1907-1909), en «Revista de Trabajo». n. 46. Madrid. 1974. 
«Solidaridad Obrera» tuvo una destacada actuación en la Semana Trágica de Barcelona. En la provincia de Alicante, la agitación contra la guerra de Marruecos de 1909 contó también con la participación de los anarquistas, sobre todo en Alcoy - colaborando con socialistas y republicanos radicales, dirigidos éstos por Botella Asensi, que fue procesado por publicar un manifiesto y encabezar una manifestación de protesta-. Hubo varios heridos y numerosos detenidos, y una huelga general que duró cuatro días. Al final de esta protesta contra el envío de tropas a Marruecos cincuenta y cuatro alcoyanos fueron procesados por sedición o agresión a la fuerza pública ${ }^{56}$.

Tras la represión subsiguiente a la Semana Trágica, hubo un recrudecimiento de los conflictos sociales. En "Solidaridad Obrera» se recibían sugerencias de numerosas sociedades de localidades no catalanas en el sentido de extender a todo el estado esa organización sindical; de otro lado, los socialistas dudaban respecto a la táctica a seguir, ante la aparición de la Conjunción Republicano-Socialista. Por fin se celebró un Congreso Obrero Nacional, durante los días 30 y 31 de octubre y 1 de noviembre de 1910, en el Palacio de Bellas Artes de Barcelona, que daria lugar a la Confederación Nacional del Trabajo.

En este Congreso de constitución de la C.N.T. participaron algunas sociedades obreras alcoyanas: según Cuadrat ${ }^{5}$, Alcoy estuvo representada por Rogelio Cantó y Rafael Bernabeu, en nombre de los Tejedores Mecánicos y la «Unión del Arte Textil», aunque hay alguna confusión al respecto ${ }^{58}$. De la lectura de las actas del Congreso se desprende que Rogelio Cantó representaba a la Sociedad de Tejedores Mecánicos "La Unica» de Alcoy, y Rafael Bernabeu a la "Unión del Arte Fabril», en tanto que la Sociedad de Hiladores Mecánicos «La Constancia» de Alcoy figuraba entre las sociedades adheridas. No hemos

${ }^{56}$ JAUME PEREZ MONTANER, Els fets d'Alcoi i la guerra del Marroc, Comunicación al I Congreso de Historia del País Valenciano.

57 XAVIER CUADRAT, De la Confederación Regional Solidaridad Obrera a la CNT, en «Revista de Trabajo» n. 48 Madrid. 1974.

${ }_{58}$ En las actas del Congreso aparece repetidas veces Rogelio Cantó como representante de los Tejedores Mecánicos de Alcoy y partícipe en los trabajos de varias ponencias. Pero en la relación final, la única sociedad de Alcoy representada es "La Unión del Arte Fabril» y, además, aparece como miembro de alguna ponencia Rafael Bernabeu, representante de "La Unión del Arte Textil» de Alcoy. Según Cuadrat, se trataría de dos entidades distintas, pero creemos que era una sola. Se extraña también Cuadrat de que los Tejedores Mecánicos aparezcan entre los adheridos al Congreso. Creemos que ello sería posible, pese a la destacada actuación de su representante Rogelio Cantó, y sería una prueba de la actitud expectante de algunas sociedades obreras ante el Congreso. En suma, pensamos que hubo en el Congreso constitutivo de la CNT una sociedad alcoyana participante - «La Unión del Arte Textil» - y dos adheridas «Tejedores Mecánicos» e «Hiladores Mecánicos»-. 
podido identificar a Rafael Bernabeu, pero sabemos que Rogelio Cantó era uno de los líderes de los socialistas alcoyanos. Cuadrat señala la intervención en el Congreso de otros socialistas, como Puig o Jacinto Durán, que trataron de impedir la conversión de la Confederación Regional Catalana en Confederación Nacional ${ }^{59}$. Resulta algo extraño que Cantó fuese en representación de los Tejedores alcoyanos, dada su ideología, pero eran momentos en que anarquistas y socialistas colaboraban estrechamente, tras los hechos de la Semana Trágica y también hay que tener en cuenta que, antes del Congreso, no estaba aún clara la definición ideológica de ese sindicalismo que estaba a punto de surgir.

Rafael Bernabeu fue nombrado para la comisión revisora de actas y participó en una ponencia sobre el trabajo de la mujer, que fue aprobada por aclamación. Mayor intervención tuvo Rogelio Cantó: junto a J. Bueso, J. Benet, M. Mañé y otros representantes de Sevilla, Barćelona y Badalona, formó parte de la Quinta Ponencia, que estudió los siguientes temas: «Medios para conseguir la jornada de ocho horas. Salario mínimo»" ${ }^{60}$ "La huelga general, para que surta efectos de eficaz defensa del proletariado, ¿puede ser pacífica o ha de ser esencialmente revolucionaria?» ${ }^{61}$ y "Cuando estando una sociedad federada en lucha es atropellada por la policía o la fuerza pública, ¿qué actitud han de adoptar las demás secciones federadas?» ${ }^{62}$. En todas ellas, se evidenció

${ }^{59}$ Sin embargo, también sabemos que Cantó estuvo trabajando durante algún tiempo en Cataluña, en el textil. Creemos, aunque no podemos probarlo suficientemente, que Cantó era ya en esos momentos hombre de ideologia socialista. En 1911, la Agrupación Socialista de Alcoy envió a Cantó a Bañeres para organizar a los obreros papeleros, entonces en huelga contra el patrono Laporta («Fraternidad», 16-III-1918) / En «El Mundo Obrero», 3-IV-1920, Cantó recuerda a J. Bueso, con quien coincidió en el Congreso de la CNT de 1911, y dice: «A últimos del año 1911, y a consecuencia de la gran huelga que sostuvo el Arte Fabril de Tarrasa, me vine a Alcoy, ausentándome contra mi voluntad de la región catalana donde tan buenos amigos tenía». ¿Confundia Cantó el Congreso de 1911 con el de 1910?.

${ }_{60}$ Para lo primero, era necesario emprender una activa campaña de concienciación, pues la lucha por el salario mínimo era fácilmente superada por el alza contínua de los precios de las subsistencias. Se acordó que, cuando la conciencia de clase estuviese firme, se decretaria «por medio de la Confederación, la conquista de las ocho horas, a la cual han de contribuir todos los obreros».

${ }^{61}$ Se acordó que la huelga general habia de ser revolucionaria, porque «la huelga general pacífica es imposible que pueda ser duradera». Ahora bien, no podia usarse a la ligera: tenía que declararse en toda la nación, cuando la Confederación se hubiese consolidado, o cuando se produjese una guerra o cuando los obreros de una localidad o provincia se viesen obligados a proclamarla por la presión de la burguesía.

${ }^{62}$ La fuerza pública, según la ponencia, estaba al servicio del capital y no del pueblo. La neutralidad de los gobiernos era pura ilusión: de ahí que todos los medios para apoyar a los obreros atropellados fuesen lícitos - mitin, boicot, sabotaje, etc. - y no podian depender más que del entusiasmo y conciencia de clase existentes en cada momento. 
ya el carácter combativo y apolítico de la Confederación, aunque todavía con algunos matices, tales como el uso moderado de la huelga general, que no se debía emplear sino «para lograr una transformación total en el modo de producir y distribuir los productos».

También participó Cantó en la discusión de otro importante dictamen: "La emancipación de los trabajadores ha de ser obra de los trabajadores mismos. ¿Cuál es la única y verdadera interpretación que debe darse a esta frase?». La ponencia hacia alusión a los trabajadores intelectuales y señalaba los peligros de que se erigiesen en directores del movimiento obrero, aunque se mostraba dispuesta a acogerlos si sustituían su ideal de encumbramiento individual por el de la emancipación colectiva. Rogelio Cantó aseguró que «a su modo de ver, son más explotados hoy en día los obreros intelectuales que los obreros del terruño y del taller» y concluyó que "no puede considerarse obreros a los que ejercen de funcionarios en las instituciones burguesas, pero si a los que trabajaban desde su bufete, desde su biblioteca o desde su cuarto de estudio para el mejoramiento intelectual del obrero».

En cambio, no intervino Rogelio Cantó en la discusión fundamental del Congreso, sobre si «Solidaridad Obrera» debía pasar, o no, a ser una Confederación Nacional. La ponencia propuso que se constituyese una Confederación General del Trabajo con las entidades no acogidas a la U.G.T. y una vez constituída «se procure llegar a un acuerdo entre las dos Federaciones, a fin de unir a toda la clase obrera en una sola organización». Según otros, "Solidaridad Obrera» debía seguir a nivel regional e incluso apuntaban que la U.G.T. cambiaría con el ingreso de una Federación Catalana en ella. Negre negó la acusación de que la nueva organización estuviese compuesta por anarquistas, pues las decisiones se tomaban con neutralidad y formaban parte de ella «obreros de todos los matices». Al final, 84 votaron a favor de la constitución de una organización nacional, 14 en contra y 3 se abstuvieron. Lo que votaron Bernabeu y Cantó, lo ignoramos ${ }^{63}$.

Pese a las críticas a la U.G.T., la recién nacida C.N.T. no presentaba una ideología decididamente anarquista. Sin embargo, el descontento que en muchos lugares - Cataluña, la propia Alcoy - había en relación a las tácticas de la U.G.T. provocaría una gradual conversión de la C.N.T. en un sindicato influído por los ácratas y los sindicalistas apolíticos $^{64}$. En los momentos de la fundación, la ideología estaba to-

${ }^{63}$ Congreso de constitución de la Confederación Nacional del Trabajo. Anagrama. Barcelona. 1976.

64 ANTONIO BAR, Algunas puntualizaciones sobre la ideología del sindicalismo radical en España, en «Estudios sobre Historia de España: Homenaje a Tuñon de Lara». Madrid. 1981. Pgs. 191-200, y La CNT en los años rojos: del sindicalismo revolucionario al anarcosindicalismo. 1910-1928. Madrid. Akal. 1981, niega también el pre- 
davía poco definida y, desde luego, era mucho más moderada que la proclamada en la citada "Carta de Amiens». Las diferencias con el sindicalismo francés eran todavía bastantes grandes ${ }^{65}$. No hay que descartar, en el retraso en constituir un sindicato a nivel estatal, la importancia de la actitud de muchos anarquistas que, desde posiciones económicas anticuadas, temían que el paso de las sociedades de oficio a las grandes federaciones de industria se hiciese en detrimento de la «ortodoxia» libertaria ${ }^{6}$.

En la provincia de Alicante, comenzaron a partir de 1910 los anarquistas a tratar de lograr una mayor presencia entre la clase obrera. Seguían contando con el problema que suponía la vigilancia y la represión de las autoridades: así, en agosto de 1910 fue detenido en Alcoy y encarcelado en Alicante José Claramunt, «de ideas avanzadas» y procedente de Barcelona; le visitaron algunos republicanos, que telegrafiaron a Emiliano Iglesias y a otros políticos para obtener su libertad ${ }^{67}$. En Alicante, los anarquistas aprovecharon la hospitalidad que les prestaba el periódico republicano «El Pueblo» para rechazar las acusaciones contra ello. Bruno Ibáñez replicó a un artículo publicado en la prensa conservadora y titulado «El terrorismo en acción»: las bombas de Barcelona las ponía Rull y los anarquistas «somos precisamente los más activos defensores de la verdadera justicia y de cuanto esté dentro de la lógica». Carlos Botella, que con Juan Gomis ostentaba el liderazgo entre los ácratas alicantinos, terció en la polémica negando que los anarquistas pusieron bombas: "Han sido siempre los anarquistas los primeros quienes han lanzado su enérgica protesta ante la faz del mundo entero en contra de estos actos de barbarie, los cuales únicamente traen consigo sembrar el espanto y el dolor entre aquellos que sufren sus consecuencias» ${ }^{\circledR}$.

dominio de la ideología anarquista en el origen de la CNT, contra lo que se venía diciendo habitualmente. Asegura, en cambio, que la CNT es consecuencia directa de la introducción en España del sindicalismo revolucionario de origen francés, que pretendía una especie de "tercera vía» entre marxismo y anarquismo, y proclamaba su apoliticismo o neutralismo ideológico. La retirada de los socialistas de la CNT dejó el campo libre a los anarquistas para un trabajo ideológico, que fue penetrando - no sin reticencias y dando origen a la corriente anarcosindicalista - en esta central sindical, a partir de su vuelta a la legalidad en la primavera de 1914.

${ }^{65}$ En el sindicalismo francés, se recomendaba un uso más frecuente de la huelga general; al sindicalismo se le consideraba no sólo un medio, sino un fin, pues sustituiría al Estado como base de la organización de la sociedad; y, sobre todo, propugnaba la C.G.T. la constitución inmediata de Federaciones de Industria, mientras que la CNT defendía la organización «en artes y oficios».

${ }^{66}$ XAVIER PANIAGUA, La ideología económica de los anarquistas en Catáluña y el País Valenciano, en "Saitabi», n. 24. Valencia. 1974.

67 "El Pueblo Republicano» (Alicante), 13-VIII-1910 / "La Voz de Alicante», 17-VIII-1910: están detenidos los «agitadores» Claramunt y Luis Granados.

"68 "El Pueblo Republicano», 30-V y 3-VI-1910. 
De la lectura de "Tierra y Libertad»" se deduce la existencia de grupos anarquistas en Alcoy, Alicante, Elche, Monóvar, Elda y Cocentaina. En Alcoy, las ideas anarquistas se propagaban con rapidez y en julio de 1910 se había formado un grupo «Pro-prensa libertaria y sindicación revolucionaria» ${ }^{70}$. En Elche, el grupo "Ser o No Ser» propuso una reunión de sociedades obreras de la provincia de Alicante para ver de salir del estado "de postración» - sería una manera de proponer la nueva organización de la CNT - y en mayo de 1911, ante el aumento de compañeros, creó un nuevo grupo anarquista, llamado "Los Antijudas»" ${ }^{71}$. En Elda se constituyó en 1911 el grupo "Los Invencibles», con José Gil, para propagar las ideas anarquistas ${ }^{72}$. Se asegura que en Alicante las ideas anarquistas estaban fermentando más deprisa de lo esperado $^{73}$ : se habia conseguido cierto peso específico en alguna sociedad obrera, como la de los Pintores, que en mayo de 1911 organizó un mitin «contra el indigno proceder de la burguesía» y en petición de la libertad de los presos sociales ${ }^{74}$.

En Agosto de 1911, poco antes del Primer Congreso de la C.N.T. - que también se celebró en el Palacio de Bellas Artes de Barcelona-, Morato hizo balance en "Heraldo de Madrid» de las fuerzas de la nueva central sindical, tomando los datos de "Solidaridad Obrera»: en Levante había cinco entidades afiliadas a la C.N.T. con 1.022 afiliados (por el número de inscritos, ocupaba Levante la tercera posición, tras CataIuña y Andalucía). En la provincia de Alicante había una sociedad afiliada a la C.N.T. en Alcoy, otra en Alicante - donde al poco tiempo ingresó una segunda sociedad - y otra en Elche. Carlos Botella asiste en representación de Alicante al Primer Congreso de la C.N.T., que se celebró en los primeros días de septiembre de 1911, e intervino en la sesión de clausura ${ }^{75}$.

La C.N.T. fue, sin embargo, puesta fuera de la ley poco tiempo después, tras la huelga general que se produjo a partir del 16 de septiembre y que provocó graves disturbios en Cullera. Esta huelga tuvo

${ }^{69}$ "Tierra y Libertad», en su cuarta época, entre el 24-11-1910 y el 31-V-1911.

70 MILAGROS RODRIGUEZ, A los anarquistas de Alcoy, en "Tierra y Libertad", 19-V-1910 (Alcoy «no irá a la zaga en la cuestión social») / ANTONIO TOMAS, A la juventud anarquista de Alcoy, en «Tierra y Libertad», 8-VI-1910 (contra la degradación en las fiestas de Moros y Cristianos) / Véase también, de este semanario, el número del 6-VII-1910.

71 «Tierra y Libertad», 26-X-1910 y 31-V-1911.

12 "Tierra y Libertad", 1-II-1911.

${ }^{73}$ MANUEL OLCINA, Para los de Alicante, en "Tierra y Libertad», 6-VII-1910. El corresponsal en Alicante era Bruno Ibáñez.

${ }_{74}^{74}$ "El Liberal» (Alicante), 27-V-1911.

${ }_{75} \mathrm{M}$. TUÑON DE LARA, El movimiento obrero en la Historia de España. Taurus. Madrid. 1972. Pág. 495. 
epercusiones en Alcoy, donde socialistas y sindicalistas colaboraron en la organización de una huelga pacífica a partir del 20 de septiembre ${ }^{76}$. La prensa de Valencia publicó alarmantes y falsas noticias sobre incendios de fábricas y conventos y asalto al cuartel de Infantería de Alcoy que fueron desmentidas por la prensa local ${ }^{77}$. Las sociedades obreras alcoyanas desconvocaron el paro el 23 de septiembre, por considerar que «nuestra solidaridad queda cumplida desde el momento que la huelga de Bilbao ha terminado ${ }^{78}$. En Alicante, las autoridades tomaron precauciones y fueron detenidos los anarquistas Bruno lbáñez y Carlos Botella, upor sus ideas avanzadas y su entusiasmo por la causa del proletariado $)^{79}$.

Para poder seguir actuando, los anarquistas acudieron entonces a la fundación de Ateneos Sindicalistas: el primero había sido organizado en Barcelona en julio de 1909. En Alicante se fundó en noviembre de $1911^{80}$ y en Alcoy en febrero de $1912^{81}$. El Ateneo Sindicalista Obrero alicantino se integró, en un primer momento, en el Centro de Sociedades Obreras, donde también tenía su domicilio la Agrupación Socialista. Se proyectaba entonces la edificación de una Casa del Pueblo y se creó una comisión gestora: muy pronto comenzaron los enfrentamietos entre socialistas y anarquistas por el control de las sociedades obreras alicantinas. En la prensa apareció un escrito de algunas sociedades obreras - entre sus representantes aparecen los destacados anarquistas Juan Gomis y Carlos Botella - que denunciaban los que consideraban manejos de los socialistas: la comisión gestora había sido elegida a espaldas de algunas Sociedades Obreras, que no estaban conformes en que la Casa del Pueblo futura «sirva de albergue a un partido político que nada tiene que ver con los Sindicatos, y que, al final, sería quien se apoderaría de todo». A ello se oponían las sociedades de canteros, torneros, barberos, panaderos, pintores y aserradores mecánicos, que declaraban no odiar a los partidos políticos, pero reclamaban igualdad para todos los obreros, fuese cual fuese su ideología política. En suma, estas sociedades obreras influídas por los anarquistas se mostraban partidarias de que la Casa del Pueblo fuese un Centro exclusiva-

${ }^{76}$ "Diario de Alicante», "El Pueblo Republicano», "La Voz de Alicante» y "La Defensa» (Alcoy), 20-IX-1911 / «Fraternidad», 18-IX-1911.

${ }_{77}$ Una novela fantástica, en "La Defensa», 23-IX-1911.

${ }_{78}^{72}$ "La Defensa», 23-IX-1911.

${ }^{79}$ "El Pueblo Republicano", 21-IX-1911.

${ }^{80}$ "Periódico para todos» (Alicante), 28-XI-1911, da cuenta de la constitución del Ateneo Sindicalista Obrero alicantino: en su directiva figuran José Guijarro, Arnaldo Manón, José Jover y otros, pero están ausentes los líderes anarquistas más conocidos. / "Diario de Alicante», 27-XI-1912: el Ateneo Sindicalista celebra velada en su primer aniversario.

${ }^{81}$ El Ateneo Sindicalista de Alcoy presenta su reglamento al Gobierno Civil. («Diario de Alicante», 24-(I-1912). 
mente obrero ${ }^{82}$.

En noviembre de 1911 fueron clausuradas en Alcoy y Alicante algunas Sociedades Obreras, por mandato judicial del Juzgado de Instrucción de Barcelona ${ }^{83}$. Ante estas medidas represivas, los anarquistas organizaron, en la medida de sus fuerzas, varias actividades en favor de los presos sociales, impulsando la formación de comités Propresos y la organización de mítines en el mismo sentido: en Elche, los anarquistas organizaron el 10 de diciembre un mitin de protesta por el encarcelamiento de obreros al que invitaron a todos los trabajadores y a los «hombres altruistas»: "Queremos la libertad de los compañeros presos por cuestiones políticas y sociales, considerando como tales compañeros a los que en todas las naciones luchan por la emancipación obrera y declarando que para su acción no reconocen los límites de la geografía oficial» ${ }^{24}$. Y en enero de 1912 se constituyó el Comité Pro-presos en Elche, en el que tenían un destacado papel los grupos anarquistas "Ser o No Ser» - que será el más duradero-, "Rebeldes en acción» y «Anti-Judas» ${ }^{85}$. En Alicante se celebró, también en enero, un mitin Pro-Presos, que presidió el citado Carlos Botella y en el que intervinieron los anarquistas Aguado, de Elche, y Catalá, de Alcoy, y los republicanos Baldomero López Arias y Pascual Ors ${ }^{86}$.

Los grupos ácratas de la provincia - en Elda, Alicante, Alcoy y Elche - actuaban como podian, a través de los citados Comités ProPresos, en el seno de las Sociedades Obreras y a través de la prensa: en mayo apareció en Elche el periódico mensual - luego quincenal, aunque su vida sería muy corta - «Liberación», que se subtitulaba «perió-

82 «El Pueblo Republicano», 14 y 18-X-1911 / Más datos sobre la polémica entre anarquistas y socialistas en torno a la Casa del Pueblo, en "Periódico para todos», 23-VIII-1911; "La Unión Democrática», 3-VIII-1911; "Eco de Levante», 23-VIII, 18 y 23-X-1911; y «Diario de Alicante», 16-XI-1911 / También en Elche, la Sociedad de Zapateros "La Racional», impulsada.por los libertarios, se negó a ingresar en el Círculo Obrero Illicitano porque alli se albergaba el PSOE (Folletos, sin fecha, titulados Sociedad de Zapateros "La Racional" y A los trabajdores con alteza de miras, en el Archivo Municipal de Elche), lo que privaba a los ácratas de ejercer mayor influencia sobre los obreros de la localidad.

${ }^{83}$ La Sociedad de Canteros de Alicante, según «Eco de Levante», 17-XI-1911 / "La Montadora» de metalúrgicos y «La Lucha» de pintores, según «El Noticiero» y «Periódico para todos», 17-XI-1911 / En Alcoy, fue clausurada la «Sociedad Unión del Arte Fabril» («La Voz de Alicante», 16-XI-1911).

${ }^{84}$ Folleto en el Archivo Municipal de Elche.

85 "La Razón» (Elche), 7-ł-1912.

${ }^{86}$ «Eco de Levante», 29-I-1912 / «Periódico para todos», 27 y 28-1-1912 / «La Voz de Alicante», 29-I-1912, asegura que la concurrencia fue "escasa en grado irrisorio». Además de la libertad de los presos, se pedía también la derogación de la Ley de Jurisdicciones, la abolición de la pena de muerte y el fin de la persecución contra las sociedades obreras («La Unión Democrática», 28 y 30-I-1912). 
dico anarquista y de propaganda sindicalista» ${ }^{87}$. En los escasos números que se conservan, se pueden leer artículos sobre el auténtico significado del Primero de Mayo, colaboraciones de Soledad Gustavo, Anselmo Lorenzo y José Prat; frecuentes polémicas con los socialistas y propaganda de folletos como «La Imprenta y la Iglesia», o «Devocionario político» - «dedicado a los santos jefes del partido obrero español»-. En el mes de julio, "Liberación» daba la noticia de la constitución en Alicante de un nuevo grupo anarquista, que tomó el nombre de «Espartaco»" ${ }^{88}$.

En los primeros meses de 1912 continuó la polémica en el Centro de Sociedades Obreras de Alicante entre anarquistas y socialistas. Según un informe publicado a primeros de mayo en «Diario de Alicante»" el Primero de Mayo publicó el Ateneo Sindicalista Obrero un panfleto en el que se criticaba a los socialistas, que convocaron entonces una reunión en el Centro de Sociedades Obreras para expulsar al Ateneo Sindicalista Obrero. Ambas partes desfilaron por el Gobierno Civil «para pedir amparo a sus respectivos derechos», cosa sorprendente en el caso de los ácratas. La asamblea fue tumultuosa: los socialistas propusieron al Consejo de Delegados la expulsión del Ateneo y pareció prevalecer este criterio; los anarquistas propusieron que tanto el Ateneo Sindicalista como la Agrupación Socialista abandonasen el Centro de Sociedades Obreras ${ }^{90}$. Los socialistas dieron tres días al Ateneo para abandonar el local, al tiempo que trataban de expulsar también a las Sociedades de Torneros y Panaderos, donde tenían gran influencia los ácratas. Los miembros del Ateneo Sindicalista se resistían a abandonar el local, alegando que estaba subvencionado por el Ayuntamiento para uso de todos los obreros, y los socialistas amenazaron con acudir a los tribunales. Poco después, la Sociedad de Torneros, Pulimentadores y Constructores de Camas pedía la expulsión, en una hoja que repartió, de la Agrupación Socialista y el Ateneo Sindicalista, «dejando al obrero libre de los políticos». Solicitaba del Gobernador Civil que, de acuerdo con la Ley de Asociaciones, hiciera salir del Centro Obrero a ambos bandos: «Trabajadores: el Centro de Sociedades Obreras debe ser para los obreros solos. ¡¡FUERA TODA POLITICA!! » ${ }^{91}$.

El asunto se resolvió con la marcha de los socialistas - a un local de la calle de Castaños y, posteriormente, a la Casa del Pueblo, en su

\footnotetext{
${ }^{87}$ Se conservan algunos números - once, entre el 1 de mayo y el 30 de noviembre de 1912- en el Archivo Municipal de Elche. Es quincenal a partir de julio.

88 "Liberación», 21-VII-1912.

89 Fraternidad obrera, en "Diario de Alicante», 3, 4 y 6-V-1912.

90 "Diario de Alicante» apoya esta solución: asi «quedarán en armonía los obreros y será una verdad llamarse el local Centro de Sociedades Obreras».

91 «Diario de Alicante», 9-V-1912.
} 
actual emplazamiento - y del Ateneo Sindicalista, que encontró acomodo en un Círculo Republicano ${ }^{92}$ " donde a partir de septiembre de 1912 llevaron a cabo diversas actividades, como charlas anticlericales y veladas literario-sociológicas ${ }^{93}$. La reapertura, en el mes de julio, de las sociedades de Canteros, Pintores y Metalúrgicos, que habían sido clausuradas tras la huelga de 1911, permitió a los anarcosindicalistas mejorar sus posiciones entre los trabajadores de la capital ${ }^{94}$.

A primeros de 1913 continuaron los anarquistas sus actividades en pro de la liberación de los presos económico-sociales. En Alcoy, la sociedad de zapateros organizó un mitin en la Escuela de Párvulos que resultó desanimado, a pesar de que se adhirieron todas las sociedades obreras ${ }^{95}$. El Ateneo Sindicalista de Alicante envió unas cuartillas -al no poder asistir - al mitin Pro-Presos que se celebró el 1 de enero de 1913 en Madrid y en el que intervinieron Mauro Bajatierra - que las leyó--, Salvador Seguí, Eduardo Barriobero, José Sánchez Rosa y Constancio Romeo ${ }^{96}$. Posteriormente, en noviembre, organizó una conferencia con participación del citado Barriobero - verdadero ídolo de los ácratas en estos años - y con presidencia de Carlos Botella: los ataques de Barriobero al clericalismo y al militarismo fueron muy aplaudi$\operatorname{dos}^{97}$.

En vísperas de la Guerra Mundial, los anarcosindicalistas continuaban su labor: denunciaban, mediante artículos en la prensa, conferencias o manifiestos con ocasión del Primero de Mayo, el peligro que suponían «esos que con el nombre de propagadores y defensores de los trabajadores, engañan a sus compañeros», los socialistas ${ }^{98}$; seguían

${ }_{92}$ «Diario de Alicante», 19-VII, 20-VIII y 13-IX-1912 / Resulta curiosa la hospitalidad de los republicanos con los anarquistas, cuando estaba vigente la Conjunción Republicano-Socialista.

${ }_{93}$ Conferencia sobre «Dios») del radical Fuentes («Diario de Alicante», 13-IX-1912); velada con textos «del sociólogo Anselmo Lorenzo» («Diario de Alicante», 19-XII-1912) y otras actividades ( «La Correspondencia de Alicante», 16-XII-1912). En enero de 1913 figuraban en su directiva José Guijarro, Manuel Esquembre, José Ribes y Vicente Oncina, entre otros («Periódico para todos», 4-I-1913).

${ }_{94}$ "Diario de Alicante», 8-VII-1912.

95 "Periódico para todos», 7-1-1913.

${ }_{96}$ "Periódico para todos», 8-I-1913.

97 "Periódico para todos», 8-XI-1913 / «Alicante Obrero», 6-XI-1913.

${ }^{98}$ Vicente Gomis, en «Diario de Alicante», 20-I-1913 / Manifiesto del Ateneo Sindicalista Obrero sobre «Origen e historia del Primero de Mayo» («La Unión Democrática», 29-IV-1913) / En un panfleto lanzado por los anarquistas de Elche el 1 de mayo de 1914, dirigido Al pueblo trabajador, compañeros hermanos de infortunio, se contrapone lo sucedido en 1886 en Chicago y la fiesta local, con gira campestre y entrega de peticiones a una autoridad que las recibía, año tras año, con total indiferencia. Al año siguiente, comparaban la celebración festiva preparada por los socialistas ilicitanos y la convocatoria anarquista del Congreso por la Paz en El Ferrol (Hojas en el Archivo Municipal de Elche). 
criticando la política y proponiendo la abstención en las elecciones ${ }^{99} y$, sobre todo, trataban de aumentar su peso específico entre la clase obrera organizada: estaban bien implantados en el textil alcoyano - la Sociedad de Tintoreros y Similares "La Emancipación» fue una de las pocas sociedades no catalanas que participó en el Congreso Nacional del Arte Fabril, celebrado en Barcelona, poco antes de la guerra mundial y en el cual se acordó la creación de la Federación Nacional del Arte Textil ${ }^{10}$, que pronto sería escenario de enfrentamientos entre socialistas $y$ anarquistas - ; dominaban el sector del calzado de Elda, donde la sociedad "La Racional» trataba de extender su influencia a Petrel ${ }^{101}$ y dominaban alguna de las sociedades obreras más combativas de la capital, como las de panaderos, pintores o metalúrgicos. "La Montadora», sociedad de los metalúrgicos alicantinos, convocó en mayo de 1914 un Congreso Nacional del oficio - que se celebró poco después en Alicante - en el que se consumó la separación de numerosas organizaciones de metalúrgicos de la Federación Nacional del oficio afecta a la U.G.T. y la constitución de una nueva Federación, adherida a la C.N.T. ${ }^{10}$.

La provinvia de Alicante era, en estos años, una de las que contaba con mayor implantación de las nuevas ideas anarcosindicalistas: como asegura Tuñón de Lara ${ }^{103}$, «la implantación regional de la primitiva C.N.T. se colige fácilmente de sus Congresos. En primer lugar, Cataluña (y particularmente Barcelona), luego Zaragoza, Valencia, Alicante, Alcoy, un núcleo muy importante en Gijón, otro en La Coruña y Vigo».

\section{ANARQUISTAS Y SINDICALISTAS ENTRE 1914 y 1917.}

En julio de 1914 se constituyó públicamente el secretariado nacional de la C.N.T., que volvía así a la legalidad. Poco después, ante el estallido de la Guerra Mundial, hubo cierta polémica entre los medios libertarios: la mayoría, desde «Tierra y Libertad» y «Solidaridad Obrera» ${ }^{104}$, sostuvieron la posición neutralista, de acuerdo con la tradicio-

${ }^{99}$ El semanario socialista «Trabajo», 24-V-1914, trata de convencerles de que voten publicando un texto de Malato, de "La bataille syndicaliste».

${ }^{100}$ Pueden leerse los Estatutos de la Federación Nacional del Arte Textil en «Boletín de Reformas Sociales", enero de 1914.

${ }^{101}$ Mitin en Petrel, en "Alicante Obrero», 8-VIII-1914, con los sindicalistas Vicente Gil, de Elda, Segundo García, de Alicante, y Antonio Loredo, de Barcelona.

102 «E Socialista», 15 y 16-IV-1814 / «Periódico para todos», 4-V, 23 y 30-VI y 1-VII-1914 / "Diario de Alicante», 30-VI y 1-VII-1914.

${ }^{103}$ M. TUÑON DE LARA, o.c. pg. 509.

${ }^{104}$ Como testimonia Pestaña, "Solidaridad Obrera» recibía dinero de la Embajada alemana, y en ese sentido, se hizo una intensa y documentada campaña contra la emigración a Francia. 
nal tónica antibelicista y antimilitarista de los ácratas; pero hubo un grupo, dirigido por Eleuterio Quintanilla y Ricardo Mella que sostuvo, en las páginas de "Acción Libertaria», una posición de apoyo a la "entente cordiale» y en contra del militarismo alemán. Como señalaba Angel Pestaña:

«lo chusco de todo esto, sin embargo, era que la mayoría de los que en Barcelona haciamos propaganda contra la guerra, y algunos de los que fuimos como delegados al Congreso de la Paz, de El Ferrol, trabajábamos para la guerra» ${ }^{105}$.

Entre los ácratas alicantinos predominó la posición neutral: así, Carlos Botella logró que el Congreso de Pintores en el que tomaba parte, en mayo de 1915, protestase por unanimidad de la suspensión por el Gobierno del Congreso de la Paz que había de celebrarse en El Ferrol, organizado por el Ateneo Obrero de aquella ciudad, de inspiración libertaria ${ }^{106}$. En el Congreso estuvieron representadas, por Antonio Loredo, las sociedades obreras de Elda, y se adhirieron - por estar de acuerdo "con los medios que acordaran para acabar con la guerra europea» - el Centro Obrero de Alcoy, la Sociedad de Oficios Varios de Alicante, el grupo "Juventud ácrata» de Elche, el grupo «Acción Social» de Alicante y la sociedad de Gabarreros del puerto de la capital ${ }^{107}$.

Con la enorme demanda de mano de obra que la neutralidad española en el conflicto europeo provocó, el papel de los sindicatos comenzó a subir. Con todo, en la C.N.T. no había todavía una política clara, por la existencia en su seno de dos tendencias básicas: la sindicalista pura y la anarquista, que recelaba de las grandes organizaciones donde peligraba, según ellos, la «pureza» de los principios. Gerald H. Meaker ha descrito así estas dos tendencias:

«El anarquismo expresaba una ética austera, una crítica casi total de la sociedad industrial burguesa y una nostalgia puritana de retorno a una era preindustrial e incorrupta; el sindicalismo, en cambio, evocaba la visión. más moderna de un mundo de obreros, racionalmente organizado, industrializado y productivo, pero expuesto al peligro de que el poder organizativo y las mejoras materiales se convirtieran en fines en sí mismos. El anarquismo, por su parte, hacía hincapié fuerte en la espontaneidad y localismo de la lu-

${ }^{105}$ ANGEL PESTAÑA, Lo que aprendi en la vida / Puede verse también la descripción que hace Victor Serge de la Barcelona de la época: «Todos éramos, más o menos, obreros de las fábricas de guerra. Paños, cueros, calzado, conservas, granadas, piezas para máquinas, todo, incluso fruta - naranjas olorosas de Valencia-, todo lo que habia en nuestras manos, todo lo que embalaban y manipulaban estaba destinado a la guerra" (G. LAPOUGE - J. BECAUD, o.c.).

106 "El Socialista», 21 y 22-V-1915.

${ }^{107}$ CARLOS FORCADELL, Parlamentarismo y bolchevización. Crítica. Barcelona. 1978. Págs. 368-370. 
cha revolucionaria; el sindicalismo implicaba una preocupación mayor por la preparación organizativa, por la planificación y por la dirección centralizada» ${ }^{108}$.

En la provincia de Alicante, en esos años, parece predominar todavía la actuación de los grupos anarquistas y el sindicalismo se encuentra aún poco desarrollado, con la excepción de Alcoy y Elda. La actuación de los grupos anarquistas se centró en la propaganda de los ideales libertarios y en la campaña en favor de los presos por motivos políticos y sociales. En agosto de 1914, el grupo anarquista de Alicante «Los Espartacos» organizó un mitin de propaganda en el Salón Moderno - «la tribuna será libre para cuantos quieran hacer uso de la palabra»-: se anuncia la visita de varios ácratas valencianos y, sobre todo, la del famoso propagandista libertario andaluz José Sánchez Rosa, al que acompañaba su hija Paca. El mitin lo presidió Carlos Botella e intervinieron también los alicantinos José Gomis y Manuel Esquembre. Sobre la asistencia, la prensa da noticias dispares: numerosa concurrencia, según algunos; menos de cien personas, según otros ${ }^{109}$.

En marzo de 1915 apareció en "Alicante Obrero" un llamamiento dirigido "a todos los anarquistas y sindicalistas de Elche» para tratar de reorganizar las escasas fuerzas allí existentes: el grupo "Ser o No Ser» y la "Juventud Acrata»" En septiembre de 1915 el mismo periódico - que con frecuencia abría sus páginas a la colaboración de los ácratas que firmaban sus artículos con pseudónimos tales como "Floreal», «Acracio del Orbe» O «L. de la Acracia» - testimoniaba la existencia de dos grupos ácratas en Elda, "Un tren en marcha» y "Los invencibles».

En febrero de 1915 se constituyó, en el Centro de Sociedades Obreras de la Avenida de Zorrilla de Alicante - donde se encontraban las sociedades obreras influídas por los sindicalistas, pues las cercanas a los socialistas se hallaban ya en la Casa del Pueblo-, una Comisión Pro-Presos, a iniciativa de la Sociedad de Oficios Varios «La Organiza-

108 GERALD H. MEAKER, Anarquistas y sindicatos. Conflictos en el seno de la CNT. 1917-1923. Akal. Madrid. 1978 / En julio de 1914, por ejemplo, el anarquista Antonio Loredo, en una charla que dió en Alicante, niega que sindicalismo y anarquismo sean lo mismo, pero se muestra partidario de la huelga general y el sabotaje, y enemigo del parlamentarismo («Las leyes pueden hacerse por medio de huelgas»): (Diario de Alicante», 11-VII-1914.

${ }^{109}$ "Periódico para todos», 8 y 10-VIII-1914 / «El Batallador» y «El Noticiero», 10-VIII-1914 / "Diario de Alicante», 8-VIII-1914 / "Alicante Obrero», 7-VIII-1914.

110 "Alicante Obrero", 26-III-1915 / En mayo de 1915, el grupo "Juventud Anarquista) de Elche lanzó un Manifiesto (Nosotros contra todos los politicos. Al pueblo trabajador, en el Archivo Municipal de Elche), con ocasión de un mitin maurista, para hacer profesión de fe antipolítica: «Somos los eternos combatidos, los siempre vilipendiados por toda laya de tiranos, por los que procuran por todos los medios conservar su imperio y su dominación sobre la masa y afirmar por la fuerza y la arbitrariedad de sus leyes, sus privilegios y prerrogativas». 
dora»"'. El Comité acordó iniciar la campaña «en pro de los desgraciados trabajadores que jimen dentro de las cárceles españolas por culpa de los mezquinos y desalmados gobernantes». Pidieron a todas las sociedades obreras que enviasen sus delegados al Comité, para que no se dijera que el asunto había sido manipulado por unos cuantos ${ }^{112}$.

El 17 de febrero, anunció el Comité un mitin Pro-Presos, con la participación de Eduardo Barriobero. La amnistía decretada en diciembre de 1914 apenas había alcanzado a algunos delitos de opinión y se consideraba una estafa para la clase obrera, al haberse excluído a los presos por cuestiones sociales, "los de Cullera, Benalgabón, Zaragoza y a cuantos tuvieron por necesidad que luchar y rebelarse contra un polizonte, burgués $u$ otro de esta calaña» ${ }^{113}$. En la convocatoria se invitaba a asistir al mitin a todos los hombres «amantes de la justicia», para conseguir la libertad de los presos - llegando, si fuera necesario, «a un paro general en España que obligara a los reaccionarios gobernantes a soltar de sus garras leoninas por la fuerza de la razón de la fuerza, la presa que hoy sostienen y que piensan devorarn-.

Al mitin asistió una «enorme concurrencia»; presidió Carlos Botella y los oradores evidenciaron posturas muy dispares. Por ejemplo, Barriobero abogó «por la unión de la falange de hombres honrados de la izquierda» imitando a la derecha que se unía para defender sus intereses; recordó que había presentado en el Parlamento una enmienda a la amnistía para que se incluyese a los obreros; se mostró partidario de «la abolición de la cárcel» al mismo tiempo que «aconseja a los obreros que estudien las excelencias del movimiento mercantil inglés, de dónde sacarán provechosas enseñanzas», y acabó su confuso y demagógico discurso afirmando que «es más partidario de la acción que de la palabra»" 11 .

En abril hubo nuevo mitin Pro-Presos: según los organizadores, el Gobierno no tenía un rasgo de nobleza y altruísmo, y por ello, sólo por medio de la prensa y de actos públicos se podría liberar a los que «lucharon por nuestros derechos de hombres", y hacer que "los malditos y enmohecidos goznes giren para abrir la puerta de la celda lúgubre $y$ den paso a un héroe defensor de los desheredados de la fortuna» ${ }^{115}$.

"1" «Periódico para todos», 10-II-1915. Componian el Comité V. Gomis, Segundo Garcia, Francisco Arenas y Bautista Casanova, entre otros.

112 «Periódico para todos», 9-11-1915.

113 "Periódico para todos», 17 y 27-II-1915.

114 «El Liberal», 28-II-1915 / "Periódico para todos», 1-III-1915 / También participó en el mitin José Llorens, "Fray Feliú», peligroso demagogo radical, que no debió de contribuir a la clarificación del acto / «El Socialista», 1-III-1915 / "La Unión Democrática», 2-III-1915.

115 «Periódico para todos», 10-IV-1915. 
En el mitin intervinieron Segundo García, Juan Gomis, Manuel Esquembre, Carlos Botella, José Ferrando y Manuel Ríos, que pronunciaron "discursos enérgicos y valientes», y propusieron emprender una gran campaña para libertar a los presos políticos ${ }^{116}$. En mayo de 1915 y a lo largo de 1916 siguieron organizando los anarquistas estas actividades.

Los anarquistas, desde las sociedades obreras en las que estaban implantados, colaboraron también en diversos actos que se organizaron en Alicante contra la carestía de las subsistencias y la crisis de trabajo, derivadas de la especulación surgida al calor del conflicto europeo, desde 1915. Pero pronto evidenciaron un deseo de desmarcarse de otras opciones como la republicana o la socialista. Por ejemplo, en febrero de 1915 se celebró un mitin unitario en la Plaza de Toros de Alicante.

«para pedir a las autoridades la resolución de la actual crisis de trabajo, que llega a ser insoportable y que se achaca a la guerra actual, que sólo sirve para que unos cuantos hagan su negocio mientras la miseria llega a la mayoría de los hogares: la guerra sólo es la excusa para el encarecimiento con el que hombres sin conciencia explotan al pueblo y roban a mansalva. Las autoridades se encogen de hombros o se dan por vencidas al primer obstáculo».

La actitud de los oradores fue muy diversa: los representantes de las Sociedades Obreras censuraron a autoridades e industriales, acusaron de cobardes a los obreros porque «ha sonado la hora de tomar por la fuerza en vez de pedir suplicando", el anarquista Segundo García aseguró que la solución era «ir a los almacenes donde se acaparan las subsistencias y tomar alli lo que se necesite», en tanto que el concejal republicano Pascual Ors aprovechó la ocasión para alabar la actuación de los republicanos en el Ayuntamiento y pedir la dimisión del Alcalde ${ }^{117}$. Inmediatamente se produjo una reacción en contra de las sociedades obreras influídas por los anarquistas, que retiraron su adhesión al mitin «por entender que fue un acto puramente político y personalista». Estas sociedades - los Canteros, "La Organizadora», etc. - aseguraban estar persuadidas «de que toda clase de política es mala dentro de las luchas económico sociales, no queremos servir de testaferros de redentores de oficio" " 18 y protestaban de los intentos "de encauzar a las masas inconscientes por derroteros perjudiciales, de ningún fin práctico ni positivo», manifestando que sus sociedades obreras estaban forma-

116 «Periódico para todos», 13-IV-1915 / «La Unión Democrática», 14-IV-1915.

117 «Periódico para todos», 8-II-1915 / «El Batallador», 5, 6, y 8-II-1915. En el mitin, la mesa estaba cubierta por un paño rojo y la inscripción «Proletarios de todos los paises, UNIOS».

${ }^{118}$ Sobre el mitin, en «Periódico para todos», 9-11-1915. Nota de la Sociedad de Canteros de Alicante. 
das por "obreros que detestan la política, sea la que fuere» ${ }^{119}$. Segundo García, orador en el mitin y destacado anarquista, lamentó en un arículo el giro dado al acto por la intervención de Ors e insistió en la necesidad de una acción directa:

«Compañeros: El pedir pan y trabajo teniendo salud perfecta y hermosa fuerza hercúlea para producir lo suficiente para nuestros hijos y nosotros, es detestable; esto ningún obrero consciente lo creerá lógico; pedir es propio de mendigos, nosotros no debemos, compañeros, de ser mendigos, sino hombres, capaces de derrumbar a todos los gobiernos, únicos causantes directos de la crisis que actualmente lamentamos» ${ }^{120}$.

Comenzaron, de otro lado, los intentos de consolidar la organización sindical, mediante charlas sobre las características de la C.N.T. y sus diferencias con los sindicatos socialistas: a finales de marzo de 1914 habló en el Centro de Sociedades Obreras alicantino Joaquín Elizondo, sobre "Orientación social»: expuso las ventajas del sindicalismo sobre la U.G.T. y se "declaró amigo de la violencia para alcanzar mejoras»" ${ }^{21}$. En octubre de 1915 hablaron en Alicante y Alcoy los propagandistas Ramón Insa, de Valencia, y el argentino Equisnain sobre «Organización obrera» y «La política y los obreros» ${ }^{12}$. En enero de 1916 la activa sociedad de panaderos "La luz del día» organizó otra conferencia parecida en el Centro de Sociedades Obreras de Alicante, con intervención de Satrústegui, de La Felguera, sobre "El malestar social» ${ }^{23:}$ : según los panaderos, había que multiplicar este tipo de actividades porque «la clase proletaria huye como alma que lleva el diablo de los Centros Obreros... una grande apatía hacia la organización reina entre los trabajadores... Los trabajadores de esta capital levantina van de fracaso en fracaso, y esto da margen a la burguesía para envalentonarse».

En Alcoy, la táctica anarcosindicalista predominaba en el sector textil. En el II Congreso de la Federación del Arte Textil, celebrado en Barcelona en marzo de 1915, el delegado alcoyano, Iborra - que intervino en el mitin final junto a Largo Caballero y Besteiro-, criticó desde sus posiciones anarquistas la actuación del secretario, el socialista Perlasia - a cuya retribución se opuso- - Hubo en ese Congreso una fuerte lucha entre los socialistas, que fracasaron en su intento de que la Federación ingresase en la U.G.T., y los anarquistas, que consiguieron enviar

119 JUAN GOMIS, Gato por liebre, en «Periódico para todos», 11-II-1915: "Los obreros no queremos compañeradas con políticos disfrazados de obreros».

${ }^{120}$ Ya esta resuelta la crisis en esta localidad, irónico artículo de SEGUNDO GAR-

CIA, en «Periódico para todos», 9-II-1915.

121 "Periódico para todos», 1-IV-1914 / «Alicante Obrero», 1 y 2-IV-1914.

122 "Alicante Obrero», 15-X-1915.

123 "Alicante Obrero», 7-|-1916. 
una representación del Congreso a la reunión de La Paz en El Ferrol ${ }^{224}$. Se acordó que el III Congreso de la Federación del Arte Textil de España se celebrase en Alcoy - pues, en junio de 1914, habían ingresado en ella todas las sociedades obreras alcoyanas del sector--, pero en diciembre el Comité, que residia en Mataró, propuso que se celebrase en Igualada, pues en Alcoy «las representaciones al mismo serían escasas, por residir el núcleo mayor de nuestras fuerzas organizadas en Cataluña» ${ }^{225}$. El secretario de la Federación seguía siendo el socialista Perlasia, quien en agosto de 1915 enviaba a "El Socialista» una nota en que, ante la propuesta hecha por la Federación del Arte Textil de Alcoy de promover un paro general en toda España contra la intransigencia patronal, se alababa la energía y combatividad de los alcoyanos, pero se consideraba inoportuno «lanzarse a la aventura de una huelga general de todo el ramo" ${ }^{26}$.

Habia, pues, claras diferencias entre el Comité Nacional y la Federación del Arte Textil alcoyana, claramente controlada por los anarcosindicalistas. La dirigía el ácrata Antonio Iborra y agrupaba a Selfactineros, Tejedores Mecánicos, Borreros y Tintoreros - que habian abandonado el Centro "El Progreso», dominado por los socialistas, y pronto dejarian la U.G.T. - , y otros oficios del textil ${ }^{127}$. Poco después, aprovechando la época de buenos negocios del sector por los pedidos del ejército francés, se lanzó una ofensiva para mejorar las condiciones de trabajo, que se extendió a localidades cercanas como Cocentaina y Bocairente ${ }^{128}$. Se llegó a una huelga general del sector que afectó a varios miles de obreros y aunque los resultados obtenidos no fueron espectaculares, funcionó bien la solidaridad entre los obreros y aumentó el prestigio y la afiliación al sindicato.

Con ocasión de la huelga, hubo fuertes enfrentamientos con los socialistas, que se remontaban a las interrupciones hechas por los ácratas en una charla de Andrés Saborit y Virginia González, en el mes de marzo, que provocaron un manifiesto de los socialistas retirándose de la vida política local y dándose de baja en las sociedades obreras de la manufactura de la lana - que, como hemos visto, estaban controladas por los libertarios-. Según los socialistas, se les acusó falsamente de ac-

124 «El Socialista», 25 y 26-III-1915 / «Alicante Obrero», 24-III-1915/ «El Popular» (Alicante), 26-III-1915 / A. BALCELLS, La mujer obrera en la industria catalana durante el primer tercio del siglo XX, en Trabajo industrial y organización obrera en la Cataluña contemporánea. Laia. Barcelona. 1974.

125 «El Socialista», 23-XII- 1915.

${ }^{126}$ "El Socialista», 7-VIII-1915.

127 "Fraternidad", 27-III-1915.

128 "Alicante Obrero», 1, 4, 5 y 7-X-1915. 
tuar como esquiroles en la huelga ${ }^{29}$ y la Federación del Arte Textil alcoyana, al terminar el paro, envió a la prensa provincial y nacional ${ }^{130}$ el acuerdo tomado por todas las sociedades obreras que componían la Federación de «no dar ingreso a ningún socialista, por haber traicionado el último movimiento, dándose de baja cuando estalló la huelga».

Una labor semejante llevaba en Elda la sociedad de zapateros «La Racional», que anunció la salida de un periódico titulado "Guerra Social» y trató de extender las ideas sindicalistas en Mónovar, Sax, Petrel y Villena, donde predominaba "el ambiente socialista» ${ }^{131}$. "La Racional» consiguió, aprovechando también la buena época por la que atravesaba el sector del calzado, que fabricaba para los ejércitos franceś e inglés, varias mejoras, en conflictos sociales y en una huelga general, en apoyo de las aparadoras, que solicitaban unificación de salarios y el reconocimiento por parte de los patronos de la sociedad obrera, en 1914 y 1915.

En Alicante, los anarquistas controlaron uno de los conflictos más duros de estos años: la huelga de los metalúrgicos, que contó con la solidaridad de sus compañeros de Alcoy, contra los propietarios de la fundición Aznar. "La Montadora», sociedad de los metalúrgicos alicantinos, organizó numerosos mítines para mantener la solidaridad y contó con el apoyo de otros oficios: la táctica era ya abiertamente de enfrentamiento sin matices con el capital y los oradores, muchos de ellos anarquistas, hablan de la necesidad de que el obrero esté dispuesto a morir en la calle en lugar de hacerlo al pié de su maquinaria, de que "el pan se busca y no se pide», de que hay que proclamar "la huelga general revolucionaria, único medio para combatir al odioso capitalismo», en suma, de la "acción directa»: de ahí que en alguna ocasión todos los oradores que tomaban parte en un mitin fuesen llamados a declarar ante el juez de instrucción ${ }^{132}$.

En todos estos conflictos eran frecuentes los enfrentamientos con los socialistas, produciéndose numerosas polémicas. "Alicante Obrero», un diario muy demagógico, sirvió de portavoz de las posiciones de los anarquistas, que publicaron varios artículos sobre la inutilidad de la política para resolver los problemas sociales, artículos que eran contestados por los socialistas y también por los republicanos ${ }^{133}$. Por su

\footnotetext{
129 SANTIAGO GADEA, De cara al enemigo. Contra una campaña difamadora, en «Trabajo» (Elche), 17 y $24-X-1915$.

${ }^{130}$ Se publicó en «Alicante Obrero» y en «Solidaridad Obrera».

131 "Alicante Obrero», 4-XII-1915.

132 "Alicante Obrero», 18-XII-1914.

133 ENRIQUE DUBOIS, La politica es una farsa, en "Alicante Obrero», 22-XII-1914 / Rafael Sevila Linares pide al obrero que confie en los políticos que le apoyan, en «La Unión Democrática», 24-XII-1915 / Para «Alicante Obrero», 29-I-1915, los políticos «son peor que los gitanos, engañan al que pueden, sea el que sea». Sus redactores se defi-
} 
parte, los socialistas utilizaban las páginas del semanario ilicitano «Trabajo» para criticar a los anarquistas ${ }^{134}$. Para los socialistas, el sindicalismo comenzaba ya a ser un claro peligro, como señalaba Largo Caballero en una conferencia que dió en Elche en 1915: «no hay que interpretar el socialismo con el sindicalismo, siendo el sindicalismo el que por no tener disciplina hace fracasar a las masas obreras... pues esos propagandistas de la acción directa se esconden en el momento oportuno y se humillan a la autoridad $\gg{ }^{135}$.

La vigilancia de las autoridades sobre los medios libertarios era constante. Veamos algunos ejemplos: en abril de 1915 se celebró en la Audiencia de Alicante un juicio contra Fernando Claramunt, «agitador libertario», por quebrantamiento de condena. Claramunt alegó que había creído que estaba afectado por la amnistía ${ }^{136}$. La prensa publicaba con frecuencia rumores sobre la presencia en Alicante de «peligrosos agitadores anarquistas», en ocasiones con cierto humor: "¡Recorcho! El Director General de Seguridad ha telegrafiado al señor Gobernador Civil de la provincia notificándole que el anarquista Francisco Miranda, que se hallaba en Barcelona, ha salido de aquella capital dirigiéndose a Alcoy para hacer propaganda. Con tal motivo se encarece la estrecha vigilancia del mencionado individuo" ${ }^{137}$. En noviembre de 1916 se dirigè Ceferino Gil al Gobierno Civil, a través de la prensa, para protestar de la vigilancia de que es objeto, al acabar de salir de la cárcel tras doce años de encierro: «¿Se puede ser ácrata? Las ideas no son un hecho delictivo» ${ }^{138}$. En ese mismo mes, el anarquista de Villena Enrique Guardiola ve prohibida por la Guardia Civil local su presencia en unos actos organizados por la clase obrera del lugar contra la carestía de las subsistencias, con la excusa de que «no podían tomar parte en dichos actos ni sindicalistas ni anarquistas» ${ }^{139}$.

nen asi: «No somos políticos, no somos socialistas, no somos anarquistas: somos obreros, somos como tú, explotados que producimos, y por tanto, deseamos, como nos pertenece, alimentar nuestros estómagos, después de alimentar nuestro cerebro y nuestro corazón», («Alicante Obrero», 17-II-1915) / En diciembre de 1915 hay una nueva polémica sobre el tema en "Alicante Obrero», entre ANTONIO CORREA, ¿Le conviene al obrero ser politico?, y J. BOTELLA, ¿Ser obrero quiere decir ser político?.

134 "Trabajo», 9-XI-1915 / En mayo de 1916 hay una polémica sobre el tema entre "Trabajo» y «La Libertad», donde Francisco Navarro pregunta a los socialistas: «¿Y en los calabozos cuántos correligionarios teneis pagando las consecuencias del actual régimen?» (14-V-1916).

135 "Trabajo», 2-V-1915.

136 "Diario de Alicante», 21-IV-1915.

${ }_{137}$ "Periódico para todos», 10-VII-1916.

138 "Alicante Obrero», 29-XI-1916.

${ }^{139}$ Denunciamos al Sr. Gobernador, en «El Luchador», 16-XI-1916 / «El Socialista», 26-XI-1916. Los concejales socialistas de Villena intervienen en favor de Guardiola, 
A lo largo de 1916 aumentó la actividad de los anarcosindicalistas en la provincia de Alicante. En la capital, la sociedad de Oficios Varios "La Organizadora» se convirtió en la punta de lanza del sindicalismo tratando de integrar a las sociedades del Centro Obrero de la Avenida de Zorrilla en la C.N.T.: propuso la publicación de un periódico ${ }^{140}$, convocó a los trabajadores de otros oficios para que se reorganizasen ${ }^{141} \mathrm{y}$ montó actos de propaganda societaria: "Las organizaciones obreras frente a los problemas actuales", charla de Antonio Loredo en febrero, y mítines de controversia en abril, a cargo de los también anarquistas Juan Gomis y Francisco Aguado, sobre la autonomía de los sindicatos obre$\operatorname{ros}^{142}$. Por otro lado, en muchas sociedades obreras se iba poniendo de manifiesto la necesidad de alcanzar un tipo de organización más amplio que la mera sociedad de oficio y de potenciar, por tanto, un sindicalismo más solidario: se constituyó asi en Alicante el llamado "pacto de unión», que comprendia a las sociedades "La Marítima», "La Terrestre» y "La Paz», de trabajadores del puerto, a los Carreros, a los Toneleros y Aserradores Mecánicos y a los Dependientes de Fábricas y Almacenes - germen de lo que seria, en 1919, el Sindicato Unico del Transporte en Alicante-; esta alianza tenía como misión fundamental actuar conjuntamente - sus miembros podían paralizar el tráfico comercial alicantino - en casos excepcionales, como se demostró con ocasión del apoyo mostrado por esas sociedades a los obreros marítimos de "La Naval» en su huelga del verano de 1916 contra las navieras.

Por iniciativa anarquista se celebraron también varios mítines en favor de los presos sociales. En el mes de febrero, la citada Sociedad de Oficios Varios propuso celebrar uno «en pro de los compañeros catalanes, por los atropellos de que vienen siendo víctimas por parte de la burguesía y autoridades" ${ }^{143}$. Poco después, la sociedad de zapateros «La Racional» de Elda propuso que se diese al mitin un alcance provincial, como así se hizo, para «ver si por este medio logramos arrancar de las argóstulas (sic) a tan. dignos compañeros... que su único delito ha sido defender a sus compañeros de sufrimientos» ${ }^{144}$. Al acto se adhirieron, además de los organizadores, varias sociedades obreras de Ali-

que dirige una carta abierta al Gobernador protestando de tales persecuciones. El teniente de la Guardia Civil alega «órdenes recibidas desde arriba». No cabe duda de que las autoridades veían con mucho más recelo la intervención de los anarcosindicalistas en la campaña contra la crisis de trabajo y la carestía de la vida, que la de los socialistas.

${ }^{140}$ "Periódico para todos», 9 y 10-II-1916.

141 "Periódico para todos», 9-III-1916.

142 "Periódico para todos», 6-IV-1916 / «El Luchador», 15-IV-1916.

143 "Alicante Obrero", 9-II-1916.

144 "Alicante Obrero», 17-11-1916 / «Periódico para todos» y «El Luchador», 18-11-1916. 
cante, la Federación del Arte Textil de Alcoy, los Albañiles de Novelda, las sociedades de Oficios Varios de Sax y Bocairente y el grupo «Paso a la anarquía» de Villena, es decir, la mayoría de las organizaciones de orientación anarcosindicalista de la provincia. Las intervenciones fueron muy radicales: el representante de la sociedad alicantina «La Defensa» asegura que los mítines no sirven para nada y que la sociedad que representa "opina que se debe recurrir a otros medios»; otro orador pide más acción y menos palabras; Marcelino Gil asegura que «el obrero debe pedir siempre con virilidad y no como hembra lo que le corresponde», el alcoyano lborra asegura que «todos los partidos políticos son funestos para la nación y en particular para el obrero» ${ }^{15}$. Como se puede advertir, este mitin pro-presos era, al mismo tiempo, una forma de afirmación de las tácticas de la C.N.T., lo que explicaría la reticencia de los socialistas alicantinos a intervenir en este tipo de actos, como se probaría en otro mitin, organizado por los panaderos alicantinos de la sociedad "La luz del día», en mayo, para solicitar el perdón de los condenados a muerte por los sucesos de Cenicero, «protestar del empleo de la fuerza armada en los conflictos públicos suscitados entre patronos y obreros» y «solicitar la abolición de la pena de muerte» ${ }^{146}$. Los socialistas no intervinieron ni se adhirieron al acto - al que asistie-

ron pocos obreros--, lo que provocó una polémica en la prensa local ${ }^{147}$. También lanzaron las Sociedades de tendencia anarcosindicalista una campaña de recogida de firmas en favor de la libertad de José Castellvi, que llevaba 22 años en la cárcel: en ambos Centros Obreros, en las estaciones, fábrica de tabacos y en el puerto se llegaron a recoger 2.132 firmas ${ }^{148}$.

En Alcoy, la Federación del Arte textil convocó en enero de 1916 un mitin para protestar de la carestía de la vida - se pidió una rebaja del cincuenta por ciento en las subsistencias y del veinticinco por ciento en los alquileres - y para pedir la libertad de los trabajadores detenidos en Barcelona ${ }^{149}$. Poco después, el 13 de febrero, celebró la Federación una asamblea local, con delegados de todas las Sociedades Obreras del Ramo, que volvió a demostrar el predominio de las tácticas anarcosindicalistas. Se debatió, en primer lugar, la conveniencia de causar baja en la Federación Nacional del Arte Textil, a la vista de las diferencias de táctica existentes: se acordó seguir en ella, pero «protestar de

145 "Periódico para todos», 21-II-1916 / «El Luchador», 18 y 21-II-1916 / "Alicante Obrero», 22-II-1916.

146 "Periódico para todos», 15-V-1916 / "Alicante Obrero», 16-V-1916.

${ }^{147}$ Los socialistas pidieron también el indulto de los presos de Cenicero, pero no se adhirieron al mítin por la campaña difamatoria que algunas sociedades obreras llevaban contra ellos.

148 "Periódico para todos», 12 y 24-VI-1916.

149 "Diario de Alicante», $y$ «El Socialista», 25-I-1916. 
la conducta observada por el Comité Nacional del Arte Textil y que sean sustituídos dichos individuos por otros». Luego se planteó si "sería de utilidad el formar una Federación local de todos los oficios» y se acordó trabajar en ese sentido, para conseguir un Sindicato Unico de Trabajadores, de la misma forma que se había conseguido unficar a la manufactura de lana. Otros acuerdos tomados fueron la realización de propaganda sindical por los pueblos limítrofes, el estudio de la reducción de la jornada nocturna, la protesta por la carestía de las subsitencias y la posible publicación de un periódico como órgano de la Federación ${ }^{150}$. En marzo, la Federación lanzó una huelga en el sector textil que afectó a unos ocho mil obreros ${ }^{151} \mathrm{y}$, a partir del verano, organizó diversos actos de protesta contra la carestía de la vida, la crisis de trabajo y el mantenimiento en prisión de trabajadores acusados de delitos sociales ${ }^{152}$. En el mes de diciembre apareció un semanario, "La Lucha», órgano de la Federación del Arte Textil: desde sus columnas, anarquistas y sindicalistas animaban constantemente a los obreros en general a trabajar por su emancipación y a incorporarse a las filas de los sindicatos ${ }^{153}$.

En cuanto a los anarquistas de Elda, su acción en el terreno laboral, - con participación de "La Racional» en diversas huelgas sectoriales, que no obtuvieron demasiados logros - se vio completada por una labor propagandística por localidades cercanas, en especial en Sax - donde consiguieron organizar a parte de los campesinos - y en Villena - donde sus esfuerzos fueron vanos, ante el control socialista sobre la clase obrera de esa localidad -, y también por una labor educativa y cultural, con una Escuela Racionalista y conferencias de divulgación ${ }^{154}$.

En mayo de 1916, una Conferencia Nacional de la C.N.T. reunida en Valencia acordó incrementar la campaña de agitación en toda España contra la carestía de la vida. Como la U.G.T. acordó lo mismo en su Congreso, se dieron diversos pasos tendentes a conseguir la unidad de acción de ambas centrales, que se plasmó en un acuerdo tomado en el verano de $1916^{155}$. La campaña culminó en la huelga general de

150 «Fraternidad», 19-II-1916.

151 «La Unión Democrática», 6-IV-1916.

${ }^{152}$ Ya en marzo, la Federación del Arte Textil organizó un acto de este tipo, insistiendo mucho en la libertad de los detenidos por los sucesos ocurridos «a causa de la crisis de trabajo y del encarecimiento de las subsistencias» («Alicante Obrero», 14-III-1916.

${ }^{153}$ El periódico, que se mantuvo hasta marzo de 1917, puede consultarse en el Archivo Municipal de Alcoy.

${ }^{154}$ Asi. Vicente Gil diserta sobre "Anatomía y Fisiología» en la Escuela racionalista («Alicante Obrero», 9-V-1916).

155 MANUEL BUENACASA, o.c., testimonia la participación de los obreros levantinos en esta campaña: "Y cuando llegó el verano de 1916, estos obreros se incorporaron a la lucha nacional, unidos al resto de los trabajadores españoles, en aquellos preludios de la revolución de agosto de 1917». 
diciembre de 1916 - que ha sido analizada por mí en otro lugar ${ }^{156}$ - y en ella colaboraron socialistas y anarcosindicalistas, aunque no faltaron reticencias y problemas. Para muchos obreros, el sindicalismo era mucho más útil en esos momentos que la táctica tradicional de la U.G.T. y se les aparecía «como una institución salvadora en que cada despojado, cada injuriado, cada víctima de la injusticia social hallará no apoyo compasivo, sino solidaridad positiva, verdadero compañerismo, fuerza necesaria para su satisfacción y justificación» ${ }^{157}$.

Ya en 1917 y con anterioridad a la huelga general, los anarquistas siguieron mejorando sus posiciones entre la clase obrera alicantina. En la capital, ninguna de las más de veinte sociedades obreras existentes estaba ya afiliada a la U.G.T., pero tampoco se acababan de decidir por incorporarse muchas de ellas a la C.N.T.: pese a los acuerdos existentes a nivel estatal, socialistas y sindicalistas se miraban con recelo ${ }^{158} \mathrm{y}$ no se llegó a un acuerdo para conmemorar el Primero de Mayo. En la prensa local se debaten las causas de la división existente entre los trabajadores de la localidad ${ }^{159}$ y lo que parece evidente es el recelo de los socialistas instalados en la Casa del Pueblo a dar entrada en ella a sociedades obreras - Panaderos, Carpinteros, Ferroviarios Andaluces, etc. - con predominio anarquista. Cuando, tras la huelga general de agosto de 1917, se fusionaron, en el mes de noviembre, los centros obreros de la ciudad, incorporándose todos a la Casa del Pueblo, no se trataba más que de una tregua, a pesar de la colaboración en actos en favor de la amnistía.

En otras localidades, como en Alcoy, también pareció reinar momentáneamente la concordia tras los sucesos de agosto y en la lucha común por la liberación de los presos sociales ${ }^{160}$. La represión por la huelga de agosto - que también afectó a los anarcosindicalistas, pese a su menor papel en los hechos, pues fue clasurado el Ateneo Sindica-

156 FRANCISCO MORENO SAEZ, La huelga general de 1917 en la provincia de Alicante. Anales de la Unversidad de Alicante. Historia contemporánea, n. 2. Alicante. 1983. Págs. 225-269.

157 "Alicante Obrero», 23-VIII- 1916.

${ }_{158}$ Así lo testimonia el diario republicano «El Luchador»: «En Alicante, por desgracia, lejos de prosperar en este sentido (la búsqueda de la unidad), se ahondan las diferencias, se miran las sociedades con recelo mutuo, y por ello se aprovechan los enemigos del obrero» («El Luchador». 10-V-1917).

${ }_{159}$ Pueden leerse las justificaciones del socialista Angel Martínez - argumentando con determinados recovecos del reglamento de la Casa del Pueblo - en «El Luchador», $12,13,15,16,18$ y $19-\mathrm{V}-1917$.

${ }^{160}$ Celebración de una imponente manifestación, con más de doce mil asistentes, para pedir la amnistia, en diciembre de 1917 («El Socialista», 7-XII-1917) / Nota conjunta de Agrupación Socialista y Ateneo Sindicalista, entre otras entidades, frente a los ataques a los presos por parte de "La Voz del Pueblo» («El Liberal», "Alcoy, 15-XII-1917). 
lista alcoyano y detenidos en Alicante, Elche, Sax, Alcoy y Elda significados militantes libertarios - unió a los obreros de las distintas tendencias. Sin embargo, a partir de entonces, los anarcosindicalistas - desde sus posiciones en el textil alcoyano, el sector del calzado de Elda y distintas organizaciones obreras de la capital - acabarían capitalizando el desencanto producido entre los obreros por la fracasada huelga de 1917. Se dió origen así a una organización sindical - vagamente inspirada en los principios del anarquismo - que veía aumentar día tras día el número de sus afiliados que no se cansaban de planear reivindicaciones y de mostrar su solidaridad con otros compañeros: de ahí que la C.N.T., en 1919, lograse en la provincia de Alicante una implantación muy sólida y con una gran participación de las bases, que sólo pudo ser desmontada por las autoridades merced a una durísima represión ${ }^{161}$.

161 Para los acontecimientos de 1917, que giraron en torno a la preparación y desarrollo de la huelga de agosto y a la lucha contra la represión subsiguiente, véase mi artículo, ya citado, La huelga general de 1917 en la provincia de Alicante. 